\title{
Care and Nutrition: Concepts and Measurement
}

\author{
PATRICE L. ENGLE \\ California Polytechnic State University, San Luis Obispo, USA \\ PURNIMA MENON \\ Cornell University, Ithaca, New York, USA
}

and

\begin{abstract}
LAWRENCE HADDAD
International Food Policy Research Institute, Washington DC, USA
\end{abstract}

\begin{abstract}
Summary. - Care is the provision in the household and the community of time, attention, and support to meet the physical, mental, and social needs of the growing child and other household members. The significance of care has best been articulated in the framework developed by the United Nations Children's Fund (UNICEF). This paper extends the UNICEF model of care and summarizes the literature on the relationship of care practices and resources to child nutrition. The paper also summarizes attempts to measure the various dimensions of care. The concept of care is extended in two directions: first, we define resources needed by the caregiver for care and, second, we show that the child's own characteristics play a role in the kind of care that he or she receives. The literature summary and methodological recommendations are made for six types of resources for care and for two of the least studied care practices: complementary feeding and psychosocial care. The other care practices are care for women, breast-feeding, food preparation, hygiene, and home health practices. Feeding practices that affect a child's nutritional status include adaptation of feeding to the child's abilities (offering finger foods, for example); responsiveness of the caregiver to the child (perhaps offering additional or different foods); and selection of an appropriate feeding context. Psychosocial care is the provision of affection and attention to the child and responsiveness to the child's cues. It includes physical, visual, and verbal interactions.
\end{abstract}

\section{INTRODUCTION}

Care is the provision in the household and the community of time, attention, and support to meet the physical, mental, and social needs of the growing child and other household members (ICN, 1992). Care is manifest in six types of activities practiced by caregivers (typically women $)^{1}$ : (a) care for women, such as providing appropriate rest time or increased food intake during pregnancy; (b) breast-feeding and feeding of young children; (c) psychosocial stimulation of children and support for their development; (d) food preparation and food storage practices; (e) hygiene practices; and (f) care for children during illness, including diagnosis of illness and adoption of healthseeking practices (home health practices) (Engle, Lhotska and Armstrong, 1997).

Whether this care is provided depends on the availability of the resources for care at the household level: education and knowledge, physical and mental health of the caregiver, time, autonomy, and social support, as well as 
family economic resources. It also depends on whether provision of care receives support at community, regional, national, and international levels, although these topics will not be specifically addressed here.

Although many researchers over the past 30 years have emphasized the importance of behavioral factors for adequate child growth under conditions of poverty and food constraint (e.g., Sims, Paolucci and Morris, 1972), recently there have been attempts to assess the actual behaviors of providing care and their link to malnutrition (ICN, 1992; UNICEF, 1990).

As an analytical construct, care is still new to many outside the field of nutrition. They might ask what care is, and why is it important? For those who are familiar with the construct, care is somewhat problematic from the measurement point of view, particularly since the concept of care is rapidly evolving. They might ask how the dimensions of care are monitored for programmatic and analytic purposes. The goal of this paper is to provide an effective introduction of care to the former group and a useful summary of attempts to develop indicators of care for the latter group.

\section{THE CONCEPT OF CARE}

UNICEF (1990) original conceptual model suggested that child survival, growth, and development are influenced by three underlying factors: food security, health care and a healthy environment, and care. The novel aspect of this model was the inclusion of care as an explanatory factor. In the next five years efforts were made to define care. Currently care is defined as the practices of caregivers that affect nutrient intake, health, and the cognitive and psychosocial development of the child. ${ }^{2}$

In order to perform care practices, the caregiver needs sufficient education, time, and support. The provision of these resources by family or society can be considered care for the caregiver (Jonsson, 1995). In Figure 1, the care practices are specified, and resources for care are included. Six major categories of resources were identified from the literature: appropriate education, knowledge, and beliefs; health and good nutritional status; mental health, lack of stress, and self-confidence; autonomy, control of resources, and control of intrahousehold allocation; reasonable workloads and adequate time available; and social support from family members and the community.

Education, knowledge, and beliefs represent the capacity of the caregivers to provide appropriate care. The physical and mental health (including self-confidence and lack of stress and depression) of the caregiver represent individual factors that facilitate the translation of capacity to behavior. Finally, autonomy, workload, and social support are facilitating conditions in the family and community. Some

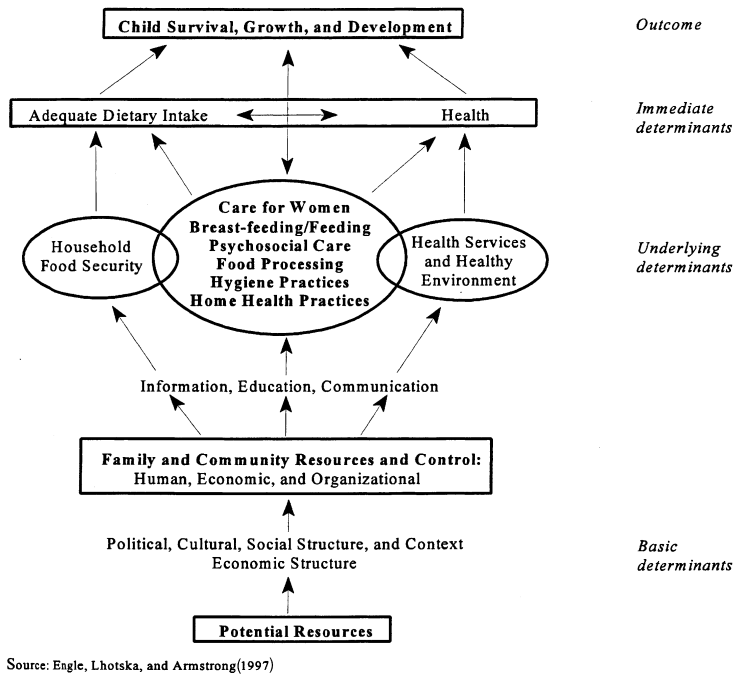

Figure 1. UNICEF's conceptual framework: Care for nutrition (Source: Engle, Lhotska and Armstrong, 1997). 
of these resource categories have been investigated extensively, whereas others have been investigated primarily in developed countries or await further investigation.

\section{(a) The transactional model of care}

The UNICEF model is a useful framework for assessing the capacity and ability of the caregiver and family to provide care. A model of child care however, should assess not only the caregiver's behavior, but also the behavior of the child and the characteristics of the child's environment. All three of these factors play a significant role in the eventual nutritional status of the child (Black et al., 1994).

For the past 25 years, psychologists have documented the significant role that children play in determining the care that they receive (Bell, 1971). Differences between children, such as endowed healthiness, perceived vulnerability, perceived weight, and even physical attractiveness, affect the practices of their caregivers. ${ }^{3}$ The transactional model of care argues that the results or effects of a child's endowments on care are a function of a long series of mutual interactions or transactions between the developing child and the caregiver, and that these interactions are constantly changing with the changing developmental status of the child (Sameroff, 1989). At the heart of the process is the relationship between the child and the caregiver (or caregivers). This affective, or emotional, relationship is a unique and life-long bond between two humans, called an attachment (Ainsworth et al., 1978). Problems in this emotional relationship can contribute to child malnutrition or ill health or may result in attachment problems. For example, Valenzuela (1990) found that in Chile, children who were undernourished were far less likely to be securely attached to a caregiver, though this association could not be interpreted as causality. The healthy development of a child has been found to depend on the development of a secure attachment or a close bond with at least one caregiver during infancy, from whom the child received abundant positive attention (Werner, 1993).

A critical aspect in the development of attachment, and the quality of care seems to be responsiveness to the child's cues, verbalizations, and signals (see, for example, Bronstein, 1991). Responsiveness does not mean that the caregiver always gives the child what is requested, but that the caregiver's response takes the child's needs and developmental level into account. Not acceding to inappropriate demands by active and well-nourished children is an important part of a caregiver's responsiveness. Usually, a positive emotional (affective) relationship between caregiver and child will be reflected in warm and responsive caregiving practices. But the lethargic or unresponsive child will have a harder time stimulating a caregiver's responsiveness.

Thus, the model of care must include the interrelationship between child and caregiver. Not only do caregiver behaviors influence child survival and development, but aspects and qualities of the child influence caregiver decisions and investments in their children. These relationships are illustrated throughout the paper.

\section{(b) The measurement of care}

There is a natural progression in research from an initial definition of relevant constructs ${ }^{4}$ to the development of valid and appropriate measurement tools, and to the definition of levels of an indicator that signal risk across cultural contexts. This process has occurred for growth, and is in process for other nutritionrelated measures such as household food security. This process is beginning for care. This paper is defining constructs, and suggesting measurement tools. Although there has been considerable progress in industrialized countries in defining constructs and measurement tools for psychosocial care, or quality of the environment (e.g., Wachs and McCabe, 1998), similar progress has not been made in developing countries, nor in relation to nutrition.

Cultural variation is likely to be a more important consideration in developing indicators for care practices than for nutritional status. Cultures differ in caregiving practices and resources. In one society, conversation-like interaction with infants is assumed to be essential for their cognitive development, whereas, in others, talking directly to an infant who cannot yet speak may have no value (Richman, Miller and LeVine, 1992). Second, care behaviors are likely to be determined by the society's perception of their goals for children. In some societies, obedience, loyalty, and hard work are valued in children, whereas, in others, verbal assertiveness and independence are valued (Nsamenang, 1992). Third, even though there may be good agreement on the constructs that are important, such as active 
feeding behaviors, and even the measurement tools, finding indicators that are not dependent on the context may be difficult. For example, active feeding of young children may be important where food is of poor quality and anorexia in children is common, whereas it may be irrelevant where there is high-quality food and little anorexia.

Crosscultural psychologists cope with this problem by proposing a model of "universalism." This theory suggests that all cultures share similar functions (for example, a greeting) but that the ways that these functions are expressed will differ by culture (wave, verbal, gaze, touching, and so forth) (Berry et al., 1992). It differs from total cultural relativity, i.e., that every culture has such different functions that one cannot make any judgments across cultures, and absolutism, which eliminates culture based on the observation that every culture has the same functions.

A number of studies have shown that withinculture differences on any measure may be as large or larger than between-culture differences. What appear initially to be unique and exotic differences between cultures are more similar when better understood (Berry et al., 1992). As indicators and assessment strategies are developed, they must focus on the function that the practice is intended to achieve within the cultural context and must measure variability within as well as between the cultures. Qualitative methods will be useful for this phase of the process.

Various measurement tools have been developed and employed to assess care. These include questionnaires or interviews asking parents or caregivers to describe their care practices and their children's typical behaviors and daily activities; qualitative rating scales with behaviorally defined scale points to assess broadly stated characteristics of care; systematic observations of the caregiver and the child in their natural setting (not in a laboratory); experimental procedures followed by observation of the child's and caregiver's responses; and coding of the frequency of particular practices. Detailed observation and coding of ongoing sequences of caregiver-child interaction, aimed at characterizing relevant features of the relationship of the pair, have also been done. The more time-intensive methods will need to be adapted for practical field use. Indicators should have meaning and validity across a variety of cultures. It is valuable to use a within-culture yardstick to compare a care- giver with others within her or his own cultural group.

It must be noted that the quality of a construct, measurement tool, or indicator will increase as more investigators and program planners use and refine them. For example, because of extensive work on measuring daily dietary intake, there are useful techniques for measurement, even though the construct of "daily intake" is complex. Similarly, the measurement of cognitive ability has received an enormous amount of attention, and numerous valid measurement tools exist. When more time is given to the assessment and analysis of care practices or behaviors, there is every reason to expect that valid measures can be developed and that indicators will eventually be defined.

Possible indicators and measurement tools for resources for care are examined in detail in the next section.

\section{RESOURCES FOR CARE}

This section summarizes the literature on human, economic, and organizational resources for care.

\section{(a) Caregiver education}

It is normally assumed that years of education is an adequate and sufficient measure. There are however, several other dimensions of education that relate to child nutrition, and might be defined as well. These pathways through which maternal education affects caregiving practices are the ability to process information, the ability to acquire skills, and the ability to model behavior.

\section{(i) Processing of information}

According to Thomas, Strauss and Henriques (1990) and Barrera (1990), it is predominantly because an educated woman is more knowledgeable that she is better able to use health care facilities, keep her environment cleaner, and thereby benefit her children. Barrera (1990) proposes that maternal education affects child health by "affecting the productivity of inputs ... and lowering the costs of information." These sources suggest that one of the likely channels through which maternal education affects child height is by improving the woman's ability to acquire new knowledge and process it appropriately. 
Information processing, measured by reading newspapers, listening to the radio, watching television, and retaining the information, differs from traditional measures of schooling because it reflects the current capacities of the woman, rather than her history. Thus it may be a better indicator of her current abilities to care for her children. These measures explain almost all of the impact of maternal education on child health, but the exact type of "information" that brought about this effect is not identified (Thomas, Strauss and Henriques, 1990).

\section{(ii) The acquisition of skills}

Skills acquisition, or material learned from school, is one way for women to build a knowledge base to guide behavior and learn patterns of practices that are useful for participating in modern bureaucracies (Joshi, 1994; LeVine et al., 1991). It is hypothesized that educated women can make better use of health care services with this knowledge, interact effectively with doctors and nurses (Joshi, 1994), and comply better with treatment recommendations (Ware, 1984). Thus the effect of schooling on child health stems primarily from the caregiver becoming literate (acquiring a skill) rather than from becoming a better "information processor" (Joshi, 1994).

\section{(iii) Identity acquisition}

The third suggestion is that women change and take on a different sense of self or identity when they become schooled. The theory of "identity acquisition" proposes that it is not literacy alone that determines the practices of educated women; schooling leads to behavior change through allowing modeling of people in the "modern sector" (Joshi, 1994). Being schooled helps women identify with the role of a teacher or their children (LeVine et al., 1991). This role change makes them more amenable to new information and also more interactive and stimulating in their child care practices.

Education, however measured, has a complex relationship with care practices. Education increases both the ability to earn income and the ability to appreciate the importance of caregiving. The former tends to mitigate against breast-feeding, particularly in urban areas, as the caregiver's opportunity cost of time increases. The latter tends to promote breast-feeding, particularly in supportive workplace environments. It can be associated with longer and more exclusive breast-feeding as well as shorter breast-feeding times. For example, in Israel, mothers with the lowest and highest levels of education engage in long-term breast-feeding (Ever-Hadani et al., 1994; Mansbach, Greenbaum and Sulkes, 1991). In developing countries, however, the negative effects on breast-feeding tend to predominate (Giugliani et al., 1992; DaVanzo and Starbird, 1991). Maternal education is associated not only with the quantity of breast-feeding (duration, frequency), but also the quality of feeding (Guldan et al., 1993). For suggested constructs and measures, see Table 1.

Better-educated women are more vocal with their infants even though their infants are likely to grow up to be more vocal themselves and therefore to require more attention as toddlers (Richman et al., 1988). ${ }^{5}$ Richman, Miller and LeVine (1992) find that better-educated Mexican mothers are more likely to feed their children when they cry. The better-educated mothers are more likely to modify their responsive practices to the age of their infants than less-educated women do. Observational studies of mother-child interactions revealed a more committed attitude toward child care among educated women (LeVine et al., 1991; Richman, Miller and LeVine, 1992). They were also more likely to take on a teacher role (LeVine et al., 1991).

Table 1. Education of caregiver

\begin{tabular}{|c|c|c|}
\hline Construct & Measurement tools & Comment \\
\hline Years of schooling & Self-report, school records, existing data & $\begin{array}{l}\text { Number of years that makes a } \\
\text { difference varies by context }\end{array}$ \\
\hline Literate or illiterate & Self-report, simple test, or existing data & $\begin{array}{l}\text { May be approximated by more } \\
\text { than } 3 \text { years of schooling }\end{array}$ \\
\hline Information processing & $\begin{array}{l}\text { Testing of functional use of language, information } \\
\text { accessing patterns (e.g., reading newspapers) }\end{array}$ & $\begin{array}{l}\text { May need to be adapted } \\
\text { to the cultural setting }\end{array}$ \\
\hline Identity acquisition & $\begin{array}{l}\text { Observation of teaching role taken by } \\
\text { mother with respect to child, professionals }\end{array}$ & Will depend on the setting \\
\hline
\end{tabular}




\section{(b) Caregiver knowledge and beliefs}

Data on cultural beliefs related to caregiving of infants are often qualitative, rather than quantitative. They can be invaluable for assessing the sociocultural causes of malnutrition, or for understanding infant feeding practices that are unique to certain cultures, before embarking on a large-scale survey. Some examples of these qualitative data are presented. Beliefs themselves however may not determine behavior. As an extensive body of social psychology research indicates, the link between beliefs, even widely held, and behavior is often weak (Wicker, 1971). A recent review of the many studies that examined the attitudebehavior link suggested that attitudes are most likely to influence behavior when there are few outside influences on behavior, and when we are more aware of our attitudes (Kraus, 1991).

\section{(i) Beliefs about illness and malnutrition}

Beliefs about illness and practices adopted during illness can have implications for children's health and nutrition. Some information about existing beliefs, in addition to the more easily available information on the use of health care facilities, may prove invaluable in the planning process in these areas. For example, certain illnesses are seen to be a part of the normal development of the child (Gryboski, 1996, in Indonesia; Cominsky, Mhloyi and Ewbank, 1993, in Zimbabwe). Some of these illnesses could precipitate malnutrition or aggravate existing situations (for example, some kinds of diarrhea and upper respiratory tract infections). In Pakistan, Mull (1991) reports that mothers seldom associate proteinenergy malnutrition (called marasmus) with consumption of too little food; it is often linked to the influence of spirits or a "bad" person on a child. Similar findings are reported in East Africa, India, Nepal, and Tanzania, where protein-energy malnutrition is often seen as a result of adultery, breast-feeding while pregnant, or an evil spirit (Gerlach, 1964; Morley, Rohde and Williams, 1983; Tanner, 1959; Reissland and Burghart, 1988).

\section{(ii) Complementary feeding}

Beliefs regarding complementary feeding have implications for child nutrition, since the age at which children are reported to be most vulnerable to growth-faltering is the period between six and 18 months, often the period of transition between breast milk and an adult diet. Some beliefs lead to too early supplementation. In Egypt, Harrison et al. (1993) report that mothers believe that supplementation at 40 days is necessary to promote growth and "fatness." Food taboos for young children may limit the types of foods that can be offered (Van Esterik, 1989). In Iran, the introduction of foods is often delayed, based on the perception that young children cannot digest the foods that are available to the family (for example, beans) or that some foods cause stammering and delayed speech (eggs) and impair the intellect if introduced before 18 months of age (cheese) (Rabiee and Geissler, 1992). In this case, children may not receive adequate amounts of protein- and micronutrient-rich foods until they are 18 months of age.

\section{(iii) Characteristics of the child that affect decisions about feeding}

Many beliefs about breast-feeding and complementary feeding depend on the caregiver's perception of the characteristics and developmental level of the child. The weaning process may be initiated because of the eruption of teeth (Almedom, 1991a, b; Harrison et al., 1993), or the onset of walking (Harrison et al., 1993). A second belief that may influence intake is that the child's appetite should determine food intake. Dettwyler, in a series of reports from Mali, finds that mothers tend to believe that children should eat only what they want (Dettwyler, 1986, 1987). Where levels of anorexia among children are high, this belief can lead to undernutrition. Engle et al. (1995) find variations in these beliefs among mothers within a single culture; mothers who felt that a child who refuses food should be encouraged to eat more had better-nourished children than those who felt that a child's refusal should not trigger offers of additional food.

Feeding may be influenced by the parent's perception of how well the child is growing. Adair and Popkin (1996) report that a mother's perception that her newborn is small decreases the likelihood of her breast-feeding, even when she intended to do so before the birth of the infant. Conversely, the perception that the infant is doing well increases the likelihood that breast-feeding will continue (Adair, Popkin and Guilkey, 1993). Among Peruvian women, Piwoz et al. (1994) report that the strongest indicator of introduction of complementary foods is low weight gain in infants. For suggested measures of beliefs and education, see Table 2 . 
Table 2. Knowledge and beliefs of the caregiver

\begin{tabular}{|c|c|c|}
\hline Construct & Measurement tools & Comment \\
\hline $\begin{array}{l}\text { Beliefs and knowledge about } \\
\text { initiation of breast-feeding, } \\
\text { colostrum }\end{array}$ & $\begin{array}{l}\text { Survey, qualitative } \\
\text { measures }\end{array}$ & $\begin{array}{c}\text { May vary both between and within cultural } \\
\text { groups; may need both an individual and a } \\
\text { normative measure }\end{array}$ \\
\hline $\begin{array}{l}\text { Beliefs and knowledge about } \\
\text { termination of breast-feeding }\end{array}$ & $\begin{array}{l}\text { Survey, qualitative } \\
\text { measures }\end{array}$ & $\begin{array}{c}\text { May vary both between and within cultural } \\
\text { groups, may depend on developmental milestones, } \\
\text { opinion of other family members, appearance of } \\
\text { other children }\end{array}$ \\
\hline $\begin{array}{l}\text { Beliefs and knowledge about } \\
\text { complementary feeding: tim- } \\
\text { ing, types, control of intake }\end{array}$ & $\begin{array}{l}\text { Surveys, qualitative } \\
\text { measures }\end{array}$ & $\begin{array}{l}\text { Child's physical and emotional state may play a } \\
\text { major role in feeding decisions or cultural beliefs } \\
\text { about personality or "personness" of the child. }\end{array}$ \\
\hline $\begin{array}{l}\text { Beliefs and knowledge about } \\
\text { maternal characteristics in } \\
\text { relation to breast-feeding }\end{array}$ & $\begin{array}{l}\text { Surveys, qualitative } \\
\text { measures }\end{array}$ & $\begin{array}{l}\text { Psychological state, maturity, and diet and health } \\
\text { of mother may affect beliefs about her ability to } \\
\text { breast-feed. }\end{array}$ \\
\hline $\begin{array}{l}\text { Beliefs and knowledge about } \\
\text { the relationship between food } \\
\text { and malnutrition }\end{array}$ & $\begin{array}{l}\text { Surveys, qualitative } \\
\text { measures }\end{array}$ & $\begin{array}{l}\text { Some illnesses are perceived as part of develop- } \\
\text { mental process (types of diarrhea, upper respiratory } \\
\text { tract infections). Caregivers may not associate } \\
\text { protein-energy malnutrition with food but believe it } \\
\text { to result from spiritual or evil influences, ill-effects } \\
\text { of breast-feeding during pregnancy, or adultery; } \\
\text { protein-energy malnutrition is often seen as a } \\
\text { stigma on the child and is deeply feared. }\end{array}$ \\
\hline
\end{tabular}

\section{(c) Physical health and nutritional status of the caregiver}

Figures on the current nutritional situation of women in the developing world indicate that iron-deficiency anemia is widespread among pregnant and nonpregnant women in developing countries, with the highest rates in South Asia (over 60\%), using a cutoff of blood levels of hemoglobin less than 12 grams per deciliter. These rates have increased in South Asia and sub-Saharan Africa over the past decade (UN ACC/SCN, 1992). Stunting and low body mass index (BMI) are common in developing countries. BMIs of less than 18.5 according to WHO (1995), also known as chronic energy deficiency, has been found in $40 \%$ of women in samples from South and Southeast Asia and in $20 \%$ in sub-Saharan Africa (UN ACC/SCN, 1992).

Maternal health could influence caregiving by reducing energy to provide care. Despite the poor nutritional situation of many women, the linkage between their nutritional status and caregiving has rarely been studied (Winkvist, 1995). Some studies do find evidence of a relationship, although with small samples. A study in Egypt indicated that anemic women were less active caregivers than non-anemic women (Rahmanifar et al., 1992). In the same study, an association was found between low levels of vitamin $B_{6}$ in mothers and failure to respond adequately to infant vocalizations. These vitamin $\mathrm{B}_{6}$ deficient mothers were also less effective in responding to infant distress (McCullough et al., 1990). It is also possible that conditions that contribute to poor maternal diet might also affect patterns of child caregiving through alternate routes, such as poverty and lack of access to adequate alternate care.

Because women with low BMI are less economically productive ${ }^{6}$ (Ferro-Luzzi et al., 1992), one could expect that they would spend more time in their homes and therefore more time in child care. There is, however, very little literature assessing the amount of child care performed with low reserves of energy. Contrary to this hypothesis, data from the Kenyan Nutrition Collaborative Research Support Program (CRSP) (McDonald et al., 1994) show that during a temporary food shortage (a famine), mothers held and cared for their children significantly less than before the shortage. The increased need to procure food resulted in increased child care by siblings and other family members. More research is needed before statements can be made about the effects of nutrient deficiencies on engagement in child care activities or responsiveness to children.

Maternal health during pregnancy could also influence the health of the newborn, which 
could influence caregiving indirectly. Maternal nutrition has a small effect on birth weight, and low birth weight is a risk factor for children's delayed development (Gülmezoglu, de Onis and Villar, 1997; de Onis, Villar and Gülmezoglu, 1998). Findings from the Egypt Nutrition CRSP (Kirksey et al., 1994) indicate that maternal intakes of energy and protein from animal sources, iron, and zinc are positively associated with neonatal "habituation" behaviors (a measure of early information processing). Rahmanifar et al. (1992) report that maternal diet during lactation, especially lower intakes of animal source foods and certain B vitamins ${ }^{7}$ are associated with infant drowsiness, and infant drowsiness is negatively associated with caregiver vocalization. Findings from the Mexico Nutrition CRSP (Allen et al., 1992) indicate that maternal weight and dietary factors are more strongly associated with infant behavioral variables, especially habituation, than are sociocultural factors.

Women between the ages of 15 and 49 in developing countries spend a significant proportion of their lives in a state of pregnancy or lactation, or both. The stresses of these periods may lead to a considerable depletion of maternal nutrient levels (Merchant et al., 1989; McGuire and Popkin, 1989). Data are not available on the effects of these factors on caregiving per se, but children of mothers who have had many children in The Gambia have poorer early growth, as well as lower rates of catch-up growth in height, than children of mothers with few children (Prentice, Cole and Whitehead, 1987). Caring for a large number of children, particularly before the older children are able to provide assistance, can also increase the workload on women. The case for improving maternal health and nutrition is stronger than ever before, based on both existing evidence of the effects of maternal health on birth outcomes and emerging evidence of their effect on infant behavior and caregiving.

Violence toward women in their homes is beginning to be acknowledged. Despite the underreporting of domestic violence, a summary of 35 studies from a variety of countries shows that "one-quarter to more than half of women report having been physically abused by a present or former partner. An even larger percentage have been subjected to ongoing emotional and psychological abuse, a form of violence that many battered women consider worse than physical abuse" (Heise, Pitanguy and Germain, 1994, p. 4). Violence toward children tends to occur in these same households, and data from the United States suggest that it is even more frequent than violence toward spouses (Finkelhor and DziubaLeatherman, 1994). An atmosphere of psychological and physical violence may have devastating consequences for children's nutritional status, but few investigators have examined the issue. For suggested measures, see Table 3.

\section{(d) Mental health, self-confidence and lack of stress}

In the United States, maternal depression is associated with poor caregiving and problem-

Table 3. Physical health and nutritional status of caregiver

\begin{tabular}{|c|c|c|}
\hline Construct & Measurement tools & Comment \\
\hline $\begin{array}{l}\text { Body mass index } \\
(\text { BMI) (weight/ } \\
\text { height }^{2} \text { ) }\end{array}$ & $\begin{array}{l}\text { Requires careful } \\
\text { anthropometry }\end{array}$ & $\begin{array}{l}\text { Usually, BMI less than } 18.5 \text { is considered } \\
\text { an indicator of risk. }\end{array}$ \\
\hline $\begin{array}{l}\text { Iron deficiency } \\
\text { anemia }\end{array}$ & $\begin{array}{l}\text { Various measures, such } \\
\text { as hemoglobin, hematocrit }\end{array}$ & $\begin{array}{l}\text { Usually, hemoglobin less than } 12 \text { grams } \\
\text { per deciliter is considered a risk factor. }\end{array}$ \\
\hline $\begin{array}{l}\text { Other } \\
\text { micronutrients }\end{array}$ & Biochemical assay & $\begin{array}{l}\mathrm{B}_{12} \text { in plasma, } \mathrm{B}_{6} \text { in breast milk, as well as a number } \\
\text { of other micronutrients (e.g., iron, zinc, vitamin } \mathrm{A} \text { ) } \\
\text { should be evaluated, since micronutrient deficiencies } \\
\text { tend to cluster in the diet of poor women. }\end{array}$ \\
\hline $\begin{array}{l}\text { Reproductive } \\
\text { health }\end{array}$ & $\begin{array}{l}\text { Number of children born, } \\
\text { birth spacing, age at first birth, } \\
\text { pregnancy complications }\end{array}$ & $\begin{array}{c}\text { Data may be available from the Demographic } \\
\text { and Health Survey or census surveys. }\end{array}$ \\
\hline Morbidity & Type, frequency, severity of morbidity & Self-report, physician's records \\
\hline $\begin{array}{l}\text { Domestic } \\
\text { violence }\end{array}$ & $\begin{array}{l}\text { May require qualitative } \\
\text { methods to obtain; low rates } \\
\text { likely from surveys }\end{array}$ & $\begin{array}{l}\text { Definitions may or may not include emotional } \\
\text { abuse. Emotional abuse has proved to be more } \\
\text { difficult to define than physical abuse. }\end{array}$ \\
\hline
\end{tabular}


atic outcomes for children (Rutter, 1990). Depression probably plays a major role in poor caregiving in many developing countries as well. But, despite reports of high levels of anxiety and depression among women in developing countries, ${ }^{8}$ studies linking these psychological factors with child care have not been done. A report on a slum improvement project in Bangladesh suggests that

the social isolation of women, coupled with the lack of extended family networks in urban areas, is thought to have negative effects on the mental health of women, which, in turn, is likely to reduce the quality of child care, even when the mother is physically present. (UNICEF, 1994, p. 9).

Depression is characterized by a lack of positive affect, energy, and optimism that appears to be excessive, given the situation. In the United States, it has been measured by a number of instruments, few of which have been adapted to other countries. But, since the most common instruments rely on self-reports (for example, the Beck Depression Inventory) and the questions are fairly straightforward, the possibility of adapting the instrument exists. An anxiety and depression scale was used, for example, in the Egyptian Nutrition CRSP project (Kirksey et al., 1992).

Stress refers to a person's discomfort when exposed to difficult and uncontrollable circumstances, and it is one of the characteristics of high-risk mothers in the United States. One more culturally flexible measure is a checklist of symptoms normally associated with stress (Weisner and Abbott, 1977). Items selected reflect psychosomatic difficulties, such as headaches, feeling tired, inability to eat, or sweating palms. Scores on the Health Opinion Survey are associated with sources of stress, such as inadequate family support among Kenyan market women (Weisner and Abbott, 1977) and problems with the spouse for Guatemalan periurban mothers (Engle, 1989b).

A commonly used measure of stress in the United States is the Life Events Change Scale, developed by Dohrenwend and Dohrenwend (1974) to measure the amount of change that an individual has experienced in a recent period. Changes, whether positive or negative, are assumed to increase stress, and they are ranked according to degree of intensity of the change. These rankings could be made within each culture, and a culture-specific scale could be constructed.
The level of confidence of the caregiver is often cited as a critical factor for complementary feeding, particularly for anorexic children, but this relationship has not been tested systematically. Program experience suggests that it plays a major role (Gibbons and Griffiths, 1984; Griffiths, 1988). Even though increased self-confidence is frequently noted as an outcome of a project, systematic measurement of this concept has eluded investigators. The measurement of self-esteem (how one values oneself compared with social norms) has a long history in the United States and numerous measurements have been developed (for example, Coopersmith, 1981). These measurements are associated with a number of outcomes, such as school performance, job success, and test scores, although relationships are not strong. Their adaptation to a broader cultural context however has been limited.

One of the difficulties in adapting the scale to other cultures is that the basis for self-esteem probably differs by culture (Berry et al., 1992). Another problem is that all of the instruments require the individual to judge whether a number of items are "like me," and this process of judging may be unfamiliar in a less selfconscious society than in the United States. Even if overall self-esteem could be measured in another culture, the scale might not measure the kinds of changes in women that are often observed in "empowerment" programs. The apparent increase in confidence often noted may be due to factors other than an increase in overall "self-esteem" such as increases in assertiveness, often very low in traditional societies (Engle, 1989b). The possibilities of developing measures of these more specific abilities are generally greater than finding a culture-free assessment of overall global selfesteem or self-rating.

Another approach is to develop a withinculture measure of self-esteem. Kurz and Ngo Som (1994) developed a self-esteem scale for adolescents in Cameroon using ethnographic techniques to construct the scale. Interviews with young adolescents gave rise to a series of descriptors. These were sorted into categories by local adolescents. Subsequently, a different group was asked to rate the terms along one of the dimensions that had emerged, a "good/ bad" continuum. A list of items was then constructed based on this continuum. In the survey, adolescents were asked to rate each word on a good/bad continuum, and then to rate how true it was of them. Their score was 
the product of the relative "goodness" of the item and how true it was of them. The resulting scale showed relatively small variability, and perhaps for that reason was unrelated to health or nutritional status. It was associated however with family living arrangements. This study illustrates the possibility of developing culturespecific systems for rating self-esteem. For suggested measures, see Table 4.

(e) Caregiver autonomy and control of resources

Autonomy and control of resources refers to the caregiver's ability to play a role in decisions made within the household and the community. A number of studies have addressed this issue. For the Côte d'Ivoire, Haddad and Hoddinott (1994), for example, suggest that mothers are more likely to allocate extra resources under their control to children than are fathers. The higher the percentage of income earned by women, the greater their control over resources (Blumberg, 1988; Engle, 1991, 1993 in Guatemala). Working for income however, does not automatically mean that women control their incomes; in many societies, income is automatically assumed to be the property of the husband (Nsamenang, 1992). Women generally enjoy greater autonomy in female-headed households, and some studies show that in spite of lower incomes, children in these living situations do better than might be expected, probably because intrahousehold distribution practices favor children more in female-headed households than in households headed by men (Haddad, 1992; Johnson and Rogers, 1993; Onyango, Tucker and Eisemon, 1994; Kennedy and Peters, 1992; and others).

In many societies, mothers do not have the authority to make decisions regarding the care and feeding of their young children. These decisions may be made by the child's father or, in many cases, by a mother-in-law or older female in the husband's family. In Jordan, Doan and Bisharat (1990) found that the most significant factor associated with child nutritional status was the degree of autonomy of the mother within the household, even controlling for the woman's age, education, and household size. Castle (1995) found that some of the most malnourished children in her Malian sample belonged to low status women in high-income households. She suggests that it may not be the level of household wealth that determines a mother's resources for child health, but rather the mother's access to these resources (Engle, Castle and Menon, 1996). For suggested measures, see Table 5 .

\section{(f) Caregiver workload and time availability}

Women's time commitments have been recognized as a zero-sum game; no new activities (including new caring practices) can be incorporated into their lives unless other activities are replaced or performed more efficiently in less time (McGuire and Popkin, $1990 \mathrm{a}, \mathrm{b})$. In addition to activities related to child rearing, women are typically engaged in other time-intensive domestic activities such as water carrying and fuelwood gathering, and nondomestic production activities, such as agricultural work, informal labor, and formal labor market activities. ${ }^{9}$ Improved collection of data on time use indicates that women spend more time than men in all work activities, and that in three Asian countries, they spend significantly more time than men in domestic production activities (United Nations, 1995; Brown and Haddad, 1995).

The literature on the effects of women's employment on child nutritional status and

Table 4. Mental health, self-confidence, and lack of stress of caregiver

\begin{tabular}{lcc}
\hline Construct & \multicolumn{1}{c}{ Measurement tools } & Comment \\
\hline Depression & Could adapt existing instruments, \\
such as Beck Depression Inventory \\
Could adapt instruments such as Life \\
Event Changes, Symptom Checklist \\
Self-confidence & $\begin{array}{c}\text { Could be adapted from other instruments; } \\
\text { includes multiple definitions because } \\
\text { it has not yet been clearly defined } \\
\text { Perceived } \\
\text { self-efficacy }\end{array}$ & Requires careful adaptation \\
& $\begin{array}{c}\text { Adapted locally as a list of tasks relevant to } \\
\text { caregiving. Woman is asked to rate her expectation } \\
\text { that she is able to perform that task. }\end{array}$ & Needs further development \\
\hline
\end{tabular}


Table 5. Autonomy and control of resources in the household by caregiver

\begin{tabular}{|c|c|c|}
\hline Construct & Measurement tools & Comment \\
\hline $\begin{array}{l}\text { Status of woman with } \\
\text { respect to others in } \\
\text { household }\end{array}$ & $\begin{array}{l}\text { Demographic survey of woman's } \\
\text { relationship to head female; } \\
\text { qualitative data; self-report }\end{array}$ & $\begin{array}{l}\text { Requires culturally } \\
\text { appropriate specification }\end{array}$ \\
\hline $\begin{array}{l}\text { Household headship } \\
\text { (female or male) }\end{array}$ & $\begin{array}{l}\text { Self-report of headship (may depend on } \\
\text { economic contribution, age, or kinship } \\
\text { patterns; reasons for absence of male partner) }\end{array}$ & $\begin{array}{l}\text { Term generates much confusion; } \\
\text { better to use several definitions }\end{array}$ \\
\hline Income earner & $\begin{array}{l}\text { Self-report (including informal labor); demographic } \\
\text { data disaggregated by gender may exist }\end{array}$ & $\begin{array}{l}\text { Income earner does not } \\
\text { necessarily control income }\end{array}$ \\
\hline $\begin{array}{l}\text { Decisionmaking } \\
\text { within household }\end{array}$ & $\begin{array}{l}\text { Caregiver's evaluation of who } \\
\text { makes decisions; survey data }\end{array}$ & $\begin{array}{l}\text { Validity of this measure may } \\
\text { be low, should interview } \\
\text { various family members }\end{array}$ \\
\hline Access to resources & $\begin{array}{l}\text { Caregiver's perception of access to family } \\
\text { income, family land, inheritance laws and customs }\end{array}$ & $\begin{array}{l}\text { May use societal } \\
\text { measures as well }\end{array}$ \\
\hline
\end{tabular}

health outcomes reveals that there is not a simple association between the two (see, for example, Leslie, 1989). Characteristics of women who work vary by economic level and context. In higher income groups, women's education is associated with working, and jobs may be formal and higher-paying. In poor populations, education tends to be unrelated to work, and poverty or female headship are associated with work, but it is often poorly paid or informal (Engle, 1993; LaMontagne, Engle and Zeitlin, 1998).

A few recent studies have found significant negative associations of work for earnings with child nutritional status (Abbi et al., 1991, in India; Rabiee and Geissler, 1992, in Iran). In both cases, women had no control over their earnings. Gryboski (1996) also found negative effects of maternal work in children who were under a year of age. Other studies have found either no negative effects of work (Wandel and Holmboe-Ottesen, 1992a, b) or positive effects of work on children (de Groote et al., 1994, in Mali; Brown, Yohannes and Webb, 1994, in Niger; Blau, Guilkey and Popkin, 1996, in the Philippines; Engle, 1991, 1993, in Guatemala; LaMontagne, Engle and Zeitlin, 1998, in Nicaragua).

There are several consistent patterns in these studies. When work was well-paid (Blau, Guilkey and Popkin, 1996), when the income was in the hands of the mother, or when the mother had adequate alternate child care and the child was more than one year old, the effects on either child nutrient intake or nutritional status were positive. Other factors that appeared to affect outcomes for children were flexibility of work, closeness of work to home, age of child, and compatibility of work with child care. Work compatible with child care can be beneficial for children, but compatible work is often informal, of low status, and poorly paid. Informal work may not be as flexible as is often assumed. For example, it may not be compatible with child care if there is much pressure to finish work by a certain time, as with piecework (Doan and Popkin, 1993; Joekes, 1989). From the literature, it appears that income-earning women who are poor, have young infants, have inflexible and timeintensive work, have little control over their incomes, or do not have good alternate caregivers may have children at risk of low growth.

Some of these variables are included in Table 6, but the remainder, as indicated in the last row, are in other tables. The use of time allocation as a measure of child care, probably the only widely used measure of child care to date, is discussed later.

\section{(g) Social support received by the caregiver}

The support provided to the primary caregiver can include explicit child care assistance or information or emotional support provided to the caregiver. One of the most important types of social support is alternate child care. The abilities of the caregiver to provide care may be particularly important for complementary feeding. Engle (1992) distinguishes between levels of care needed at various stages of development of the child. Care by anyone but the mother or a competent adult in the first year of life is associated with higher infant mortality; care needs in the second year of life are still very demanding, although the short- 
Table 6. Workload and time availability of caregiver

\begin{tabular}{|c|c|c|}
\hline Construct & Measurement tools & Comment \\
\hline $\begin{array}{l}\text { Observed time spent on } \\
\text { work and child care }\end{array}$ & $\begin{array}{l}\text { Observed in sample of time or continuously; } \\
\text { define terms as including supervision or not }\end{array}$ & $\begin{array}{l}\text { Observe all caregivers; age of } \\
\text { child will be a critical factor }\end{array}$ \\
\hline $\begin{array}{l}\text { Recalled time spent on } \\
\text { work and child care }\end{array}$ & $\begin{array}{l}\text { 24-hour recall most common; } \\
\text { should interview caregiver }\end{array}$ & $\begin{array}{l}\text { Validity of the measure may } \\
\text { be quite limited; can improve } \\
\text { measure with good interview } \\
\text { techniques }\end{array}$ \\
\hline $\begin{array}{l}\text { Work characteristics: } \\
\text { occupation, wage rate, } \\
\text { security }\end{array}$ & $\begin{array}{c}\text { Self-report, census data; often small-scale } \\
\text { informal work is not counted } \\
\text { without special effort }\end{array}$ & $\begin{array}{l}\text { Important to examine } \\
\text { control of income, alternate } \\
\text { caregivers, and level of } \\
\text { assets of household }\end{array}$ \\
\hline $\begin{array}{l}\text { Flexibility of employ- } \\
\text { ment, compatibility with } \\
\text { child care }\end{array}$ & $\begin{array}{l}\text { Work location, time-based (wage) or not, } \\
\text { transportation issues, how absenteeism } \\
\text { due to child illness is handled }\end{array}$ & $\begin{array}{l}\text { Informal work and piecework at } \\
\text { home may not be } \\
\text { flexible; depends on need for } \\
\text { income, pressures for } \\
\text { production. }\end{array}$ \\
\hline $\begin{array}{l}\text { Quality of care during } \\
\text { work time (mother or } \\
\text { other caregiver) }\end{array}$ & $\begin{array}{c}\text { Surveys, characteristics of alternative } \\
\text { caregivers (for example, age, gender) and } \\
\text { their availability; observation of } \\
\text { quality of care }\end{array}$ & $\begin{array}{l}\text { Also should assess instructions } \\
\text { to alternative caregivers, } \\
\text { amount of food preparation, } \\
\text { and so forth }\end{array}$ \\
\hline
\end{tabular}

comings of the caregiver can perhaps be ameliorated by the availability of good quality food and a healthy and safe environment. By the third year of life, many children are capable of some degree of self-care. Leslie's (1988) summary of findings suggests the possibility of negative outcomes for children of mothers who worked during the first year of life but neutral or positive outcomes in later years of life.

The quality of alternate caregiving is rarely investigated. The only dimension of quality that has been examined so far is the age of the alternate. Some studies suggest that care by a preteen caregiver is associated with lower nutritional status of the child under two years, controlling for mother's education and socioeconomic status (Engle, 1991; LaMontagne, Engle and Zeitlin, 1998). These effects are not unidirectional. Although women's work for earnings normally increases after their children pass through the critical first year, in the Philippines, women in the lowest income groups with more than one preschool child are more likely to work than those with fewer preschool children (Doan and Popkin, 1993). Presumably, they have a greater need to work regardless of the availability of alternate caregivers.

To date, the availability of institutional care for very young children is extremely limited in developing countries. But, a number of experimental attempts to provide this kind of care are underway, and some have been able to provide care for the youngest children
(Leonard and Landers, 1992). The quality of these programs depends enormously on the quality of the support provided to the personnel (Young, 1995). There are examples of community organizations that have helped increase the amount of food consumed by children when mothers were unable to do so. ${ }^{10}$

Although there is some evidence that femaleheaded households provide better care for children, the overall trend toward an increasing number of female-headed households, a higher percentage of women in the labor force, and more older family members to care for raises concerns about the burden placed on the primary caregivers-women (Bruce et al., 1995). Although men should be more involved with child care as women increase their time in the labor force, this change has been slow in coming, with men still providing far less than an equal share of time in household chores and child care (United Nations, 1995).

Fathers are particularly important as a source of emotional and informational support (Engle and Breaux, 1998). There is some evidence that when they contribute a higher percentage of their incomes to family budgets, children are better nourished (Engle, 1993, 1995). Their roles are particularly important where females are traditionally secluded, as in Pakistan (Jahn and Aslam, 1995). Their opinions about child caregiving can have significant effects on decisions about breast-feeding (Scrimshaw et al., 1987). The 
Nutrition Communication Project in Mali was successful in improving child nutritional status by actively encouraging men to alter their food purchases toward more beneficial foods for their wives and children (AED, 1995). Understanding father's attitudes and targeting fathers for education offers promise for nutrition education programs. For suggested measures, see Table 7.

\section{CARE PRACTICES}

Constructs and measurement tools are discussed for two dimensions of caring behavior: time spent (quantity of care), and the nature of the activities undertaken (quality of care), or some combination of the two dimensions.

\section{(a) Time spent on child care}

In 12 recent studies using observation and recall, time spent in child care ranged from a high of more than $7.3 \mathrm{~h}$ per day in the Philippines (Blau, Guilkey and Popkin, 1996) to a low of 18 minutes per day in the care of others by lead females in Nepal (Paolisso and Regmi, 1995; Paolisso, 1994). A number of reasons, other than actual differences in child care time, could explain the discrepancies. First, observation measures tend to reveal more child care time than recall measures. Second, the definition used for child care activities affects the results. Assessments of time spent in specific activities with children (e.g., bathe, feed) are much lower than assessments that include child watching and supervision. When supervision is included, daily means are almost five hours greater. Third, a major difference in estimates of time spent in child care depends on how simultaneous activities are coded; some are coded as separate activities, resulting in a higher total time; others ignore the secondary activity.

Fourth, age also influences child care time. Observed child care time drops dramatically after the first year or year and a half (Kenya CRSP, Baksh et al., 1994). In the Baksh study, $84 \%$ of all care activities were addressed to children from zero to 17 months of age.

Fifth, in some settings, it may be necessary to estimate child care time by alternate caregivers as well as mother time. Gryboski (1996) in Indonesia observed care by nonmothers, even when mothers were present, on $88 \%$ of days and Castle (1995) found substantial child caregiving in Mali. Finally, it is advisable to ask people to report their own time in child care. They may not be accurate in reporting time of others, including older siblings (Immink et al., 1994).

(i) Validity of recall methods for time allocation

A small number of studies have evaluated the accuracy of time use data (for example, Engle and Lumpkin, 1992; Ricci et al., 1995; Piwoz et al., 1995; Engle, Hurtado and Ruel, 1997). The standard approach is to have one person observe activities and a different person interview the subject and compare the number of activities correctly recalled and the accuracy of the duration of recall (for example, Bernard, Killworth and Salier, 1984).

Recall error rates vary significantly by type of activity. In general, memory is superior for events that are easily coded (for example, those that have a defined start or stop time) and for

Table 7. Social support for caregiver

\begin{tabular}{|c|c|c|}
\hline Construct & Measurement tools & Comment \\
\hline $\begin{array}{l}\text { Availability of } \\
\text { alternate caregivers }\end{array}$ & $\begin{array}{l}\text { Survey of caregiver when mother is working; } \\
\text { ratio of children to adults in household } \\
\text { (dependency ratio); quality of alternate caregivers } \\
\text { (for example, age); survey of whether } \\
\text { alternates are kept out of school for this purpose }\end{array}$ & $\begin{array}{l}\text { Need more information on } \\
\text { quality of alternative care- } \\
\text { giver; dependency ratio } \\
\text { should focus on children } \\
\text { under three years of age }\end{array}$ \\
\hline $\begin{array}{l}\text { Father's provision } \\
\text { of support }\end{array}$ & $\begin{array}{l}\text { Surveys on father's role in decisionmaking; } \\
\text { surveys and observations of father's sharing } \\
\text { of household and child care tasks; qualitative } \\
\text { methods used to identify other providers } \\
\text { of emotional or informational support }\end{array}$ & $\begin{array}{l}\text { Observation is difficult; } \\
\text { may use unobtrusive } \\
\text { observations of father's role; } \\
\text { important to interview both } \\
\text { men and women }\end{array}$ \\
\hline Community support & $\begin{array}{l}\text { Assessment of community institutions for child } \\
\text { feeding and care programs; qualitative focus groups }\end{array}$ & $\begin{array}{l}\text { Depends on local } \\
\text { situation }\end{array}$ \\
\hline
\end{tabular}


nonhabitual or highly salient or important events (Best, 1989). Unfortunately, child care is a frequent, nonsalient activity and is therefore less likely to be encoded and less likely to be remembered. Not surprisingly, activities such as work are recalled with reasonable accuracy; however, recall accuracy for habitual, nonsalient activities like child care is much lower (Engle and Lumpkin, 1992; Ricci et al., 1995). In a pilot study to determine whether recall could be used for the Kenya CRSP, Ricci et al. (1995) found that $83 \%$ of child care activities were not reported and concluded that observations had to be used in the study. Instructions that facilitate recall have been found to increase the accuracy of recall (Engle and Lumpkin, 1992).

Direct observation is preferable to recall because it increases the chances of getting accurate measures of time allocation and allows the investigator to assess degrees of involvement and quality of child care at the same time.

\section{(ii) Time spent on child care as an indicator of care}

Should time spent in child care be used as an indicator of care provision? Ten studies that examined the relationship were compared. The summary of studies does not lend strong support to the hypothesis that a quantitative measure of mother's time spent on child care has a significant association with child nutritional status or energy intake. Of the 10 , only two studies found that spending more time on child care was positively associated with children's anthropometric measures, both from the Philippines. In one of these two, when Blau, Guilkey and Popkin (1996) controlled for fixed effects, the only remaining associations with child weight were time spent by a nonfemale relative, and for child height, time spent by the mother.

The rest of the studies found no association between child care time and nutritional status or intake, even when child care time was observed (Gryboski, 1996; Ricci et al., 1994). Ricci et al. (1994, p. 302) reported that, in the period between 18 and 23 months of age, "maternal child caregiving behavior was critical" for energy intake, but the significant measure of care was frequency of feeding, not total time spent on child care and feeding.

This discussion leads to the conclusion that the amount of time spent on child care may not be useful in predicting whether a child's intake or its nutritional status will be ade- quate, particularly if measured by recall. Research resources may be better invested in collecting information on specific measures of care.

\section{(b) Specific care practices}

Whereas measures of time spent on child care are not strongly related to child outcomes, specific practices have often been associated with positive outcomes for children. For example, different ways of disposing of child wastes can affect incidence rates of diarrhea as can hygiene practices like boiling water prior to use (Cebu Study Team, 1991). This section discusses specific measures of two caregiving activities - feeding and psychosocial care - that are associated with child outcomes.

\section{(i) Feeding practices}

Caregiver practices that could affect the child's nutrient intake include adaptation of feeding to the child's characteristics, taking into consideration psychomotor capabilities (such as use of finger foods, spoon handling ability, ability to munch or chew) and appetite; responsiveness of the caregiver to feeding situations, including encouraging the child to eat, offering additional foods, providing second helpings, stimulating eating through threats, timing of feeding, responding to poor appetite, and interacting positively with the child; and appropriateness of the feeding situation, including the organization and regularity of feeding, supervision and protection of the child while eating, frequency of feeding, monitoring with whom the child eats, and elimination of distractions during eating (Table 8).

\section{(ii) Adaptation of feeding to child's characteristics}

Caregivers need to be sure that children are capable of self-feeding before expecting it of them. Children also have a drive for independence and may eat more if they are allowed to use newly learned finger skills to pick up foods. A child's capacity to process food by suckling, munching, or chewing increases with age. For example, by seven months of age, the "gag reflex" moves to the posterior third of the tongue, permitting the child to ingest solids more easily (Milla, 1991). The time it takes for a child to eat solid and viscous foods decreases with age, but not the time it takes to consume puréés. The child's ability to hold a spoon, 
Table 8. Feeding practices: Caregiver/child interactions

\begin{tabular}{|c|c|c|}
\hline Construct & Measurement tools & Comment \\
\hline $\begin{array}{l}\text { Presence, absence } \\
\text { of specific caregiver } \\
\text { feeding practices }\end{array}$ & $\begin{array}{l}\text { Observation of one or more eating episodes; } \\
\text { can adapt existing scales (for example, the } \\
\text { Nursing Child Assessment Feeding Scale) } \\
\text { or develop list of behaviors related to caregiver } \\
\text { responsiveness and the feeding environment }\end{array}$ & $\begin{array}{l}\text { Caregiver feeding practices } \\
\text { will depend on child behav- } \\
\text { ior, which should be re- } \\
\text { corded. May compensate } \\
\text { for child behavior problems. }\end{array}$ \\
\hline Frequency of behaviors & $\begin{array}{l}\text { Quantitative assessment of behaviors related to } \\
\text { feeding, number of spoonfuls, number of touches }\end{array}$ & $\begin{array}{c}\text { Must have careful training } \\
\text { of observers }\end{array}$ \\
\hline $\begin{array}{l}\text { Overall affective quality } \\
\text { of interaction }\end{array}$ & $\begin{array}{l}\text { Rate child and caregiver separately on } \\
\text { scales representing domains of } \\
\text { behavior with } 1-5 \text { point scales }\end{array}$ & $\begin{array}{l}\text { Distinguish failure to } \\
\text { thrive from normal } \\
\text { US inner-city children }\end{array}$ \\
\hline $\begin{array}{l}\text { Caregiver behavior in } \\
\text { a structured situation }\end{array}$ & $\begin{array}{l}\text { Present a challenge to caregiver and } \\
\text { observe what she does with the child, or } \\
\text { ask her to report the results at a later date }\end{array}$ & $\begin{array}{l}\text { More often used in qualita- } \\
\text { tive research; could be a } \\
\text { quantitative technique }\end{array}$ \\
\hline
\end{tabular}

handle a cup, or grasp a piece of solid food also increases with age.

Poor appetite plays a major role in inadequate nutrient intake of children (Piwoz et al., 1994; Bentley, Black and Hurtado, 1995). Factors that reduce a child's appetite may include a monotonous diet, lack of nutrients needed for appetite (for example, zinc), illnesses such as fever (Neumann et al., 1994), diarrhea, malaria, measles, intestinal parasites, chronic malnutrition, sores in the mouth (perhaps caused by teething), or anxiety (Dettwyler, 1986, 1987). These problems are not unique to malnourished children; as noted earlier, $24 \%$ of parents in affluent societies report feeding difficulties with their two-year-old children. Thus the caregiver's ability to deal with child anorexia is significant for child intake. For suggested measures of feeding practices, see Tables 9 and 10.

\section{(iii) Caregiver's ability to feed responsively}

Particularly with young children, feeding can be an active process: caregivers can encourage, cajole, offer more helpings, talk to children while eating, model eating behavior, and monitor how much the child eats. In many societies, caregivers are passive feeders, leaving the initiative to eat to children (the child controls the feeding) (Dettwyler, 1987; Bentley et al., 1991; Engle and Zeitlin, 1996). At the other extreme are cultural patterns that support caregiver control of eating, characterized by forced feeding and continued and even intrusive pressure on children to eat (Brown et al., 1988; Launer and Habicht, 1989). In this case, rather than providing an opportunity for interaction and educational enhancement, feeding can become a time of conflict with intrusive but ineffective caregiver strategies and high levels of child refusal.

Table 9. Feeding practices: Child variables

\begin{tabular}{|c|c|c|}
\hline Construct & Measurement tools & Comment \\
\hline Appetite and hunger & $\begin{array}{l}\text { Observe whether food is completely } \\
\text { eaten or interest level during eating }\end{array}$ & $\begin{array}{c}\text { May depend on specific food or } \\
\text { initial or subsequent contact } \\
\text { with food }\end{array}$ \\
\hline $\begin{array}{l}\text { Adaptive food } \\
\text { preferences }\end{array}$ & $\begin{array}{l}\text { Observation of child's interest in } \\
\text { standard foods; survey of } \\
\text { caregiver's observations }\end{array}$ & $\begin{array}{l}\text { Children who reject major food } \\
\text { are more undernourished; high } \\
\text { incidence of "picky eaters" in } \\
\text { failure-to-thrive children }\end{array}$ \\
\hline $\begin{array}{l}\text { Child has characteristics } \\
\text { preferred (or not) by } \\
\text { parents }\end{array}$ & $\begin{array}{l}\text { Use qualitative methods to identify } \\
\text { variables - may be gender, parentage, } \\
\text { physical attributes, birth order }\end{array}$ & $\begin{array}{l}\text { These preferences are hard } \\
\text { to assess directly; may use } \\
\text { frequency of care as an indicator }\end{array}$ \\
\hline $\begin{array}{l}\text { Physical difficulties in } \\
\text { self-feeding }\end{array}$ & $\begin{array}{l}\text { Low birth weight (LBW); oral/motor } \\
\text { dysfunction as diagnosed by physician; } \\
\text { developmental delays in skills related to } \\
\text { self-feeding assessed by clinician }\end{array}$ & $\begin{array}{l}\text { LBW associated with poorer } \\
\text { suckling ability, oral/motor } \\
\text { dysfunction fairly common in } \\
\text { failure-to-thrive children }\end{array}$ \\
\hline
\end{tabular}


Table 10. Psychosocial care: Child and caregiver interactions

\begin{tabular}{|c|c|c|}
\hline Construct & Measurement tools & Comment \\
\hline $\begin{array}{l}\text { Caregiver-child } \\
\text { interaction }\end{array}$ & $\begin{array}{l}\text { Naturalistic observation of caregiver and child } \\
\text { for a short period; code variables such as delay } \\
\text { in responding, type of response, and level of } \\
\text { vocalization by caregiver and child }\end{array}$ & $\begin{array}{l}\text { Depends on age of child and } \\
\text { context; reliable and valid } \\
\text { measures have been developed; } \\
\text { key variables are time without } \\
\text { interaction, "doing nothing" }\end{array}$ \\
\hline $\begin{array}{l}\text { Caregiver-child } \\
\text { interaction rating } \\
\text { scale }\end{array}$ & $\begin{array}{l}\text { Rating of caregiver behavior in } \\
\text { structured teaching or play situation }\end{array}$ & $\begin{array}{l}\text { Allows valid measures in a brief } \\
\text { time; limited if structured situ- } \\
\text { ation is too distinct from child's } \\
\text { life }\end{array}$ \\
\hline $\begin{array}{l}\text { Overall rating of } \\
\text { environment }\end{array}$ & $\begin{array}{l}\text { HOME Scale (standardized } \\
\text { rating scale) }\end{array}$ & $\begin{array}{l}\text { Has been used in a variety of } \\
\text { cultures; needs to be adapted to } \\
\text { each setting carefully }\end{array}$ \\
\hline $\begin{array}{l}\text { Caregiver's under- } \\
\text { standing of develop- } \\
\text { mental milestones }\end{array}$ & $\begin{array}{l}\text { Assessment of caregiver's } \\
\text { judgments about stages } \\
\text { of development }\end{array}$ & $\begin{array}{l}\text { May be linked to parental } \\
\text { stimulation of cognitive } \\
\text { development }\end{array}$ \\
\hline
\end{tabular}

Passive feeding may be due to the lack of time and energy or to beliefs that children should not be pressured to eat-that "the stomach knows its limits" (Bentley, Black and Hurtado, 1995). Although this belief may seem reasonable, if a child has anorexia or a poor appetite, extra encouragement may be necessary for adequate nutrient intake. Anorexic children are difficult to feed. When anorexia is a problem, caregivers need actively to encourage food consumption. But this means having the time, knowledge, resources, self-confidence, and support to encourage anorexic children to eat (Griffiths, 1988).

Where feeding encouragement is normally low, increased encouragement of eating has been observed when children are ill (Bentley et al., 1991) or refuse food (Engle and Zeitlin, 1996). These findings suggest that active feeding may have a compensatory rather than an enhancement role. In other words, the caregiver may feed more intensively if she perceives that the child is not eating. Caregiver understanding of and response to children's hunger cues may be critical for adequate food intake. For example, if caregivers perceive a child's tongue thrust, a typical mouthing response to new food sensations at a particular age, as a food refusal and cease to feed, a child will receive less food (Kotchabhakdi et al., 1987).

Studies comparing failure-to-thrive children with normally growing children have found differences in the feeding style of the two groups. In failure-to-thrive groups, an authoritarian disciplinary approach may override children's internal regulatory system for hunger, and there may be low maternal responsiveness and sensitivity to cues. This style may be combined with family isolation and possibly with difficult temperaments or subtle oral/motor feeding problems in the children, leading to a breakdown of the caregiverchild relationship (MacPhee et al., 1993; Black, 1995). Interventions to modify these relationships through increasing family support have met with only modest success (for example, Drotar et al., 1990), although one carefully executed experimental investigation showed significant effects on cognitive development, although not growth, among children when the intervention began prior to 12 months (Black et al., 1995). Strategies that use behavior modification, including shaping of parental behavior and presentation of positive role models, have resulted in changes in feeding practices. For example, among US African-American adolescent mothers, a videotape of positive feeding practices that was culturally appropriate and relied on social learning theory resulted in significant changes in the mother's attitude toward child feeding and in observed maternal mealtime behavior such as maternal communication, amount of verbalization, and quality of verbalization (Black and Teti, 1997). For suggested measures, see Tables 8 and 9.

\section{(iv) The feeding situation}

Children can be fed on a regular basis each day, sitting in a prescribed place with food easily accessible, or feeding can occur while children wander around, or at a time that the caregiver finds convenient. Children can be easily distracted, particularly if food is difficult to eat (for example, soup with a spoon that is 
beyond the child's ability to handle) or not particularly tasty. If supervision of feeding is not adequate, other siblings or even animals may take advantage of a young child's vulnerability and take food away, or food may be spilled on the ground. Feeding from a common pot may reduce the chances of a younger child getting enough food and may make it harder for a caregiver to be sure food has been allocated to the youngest child.

Studies in developing countries have found associations between specific feeding behaviors, such as location of feeding, organization of the feeding event, and use of spoon, with mother's education (Guldan et al., 1993). The authors conclude that more educated mothers had more labor-intensive child care strategies, particularly in selecting a clean and protected location for feeding. Linkages with child nutritional status were not made.

Caregivers may not be aware of how much their children eat; one project found that when mothers paid more attention to the quantity children ate, they were surprised by the small amounts and were willing to increase amounts fed (Dickin, Griffiths and Piwoz, 1997). When children are fed from a common pot, the amount eaten is not easy to determine. Having a separate bowl for each child can help the caregiver evaluate the quantities eaten.

(v) Measurement tools to assess care behaviors and practices in feeding

Five types of observational measures have been used to examine child and parent behavior in feeding situations: observations of time spent on feeding, presence or absence of specific feeding practices, quantitative assessments (frequency of specific feeding behaviors), behavioral ratings (to measure the quality of the caregiver-child interaction), and structured situation challenge (the caregiver is presented with a new food and her reactions are observed). Recall of child or caregiver time spent on feeding, discussed in a previous section, will not be considered here.

Observation of specific practices: The most commonly used assessment technique is to code the presence or absence of child or caregiver behaviors on a series of items (Barnard et al., 1989; MacPhee et al., 1993; Engle and Zeitlin, 1996; Guldan et al., 1993). The most widely used instrument in clinical settings in the United States has been the Nursing Child Assessment Feeding Scale (NCAFS) (Barnard et al., 1989), in which the observer watches a single instance of child feeding and rates the behavior according to carefully defined operational criteria on 76 items. The authors have defined a threshold (a score of 50 or less) which has been shown to distinguish high- and lowrisk infant feeding behaviors (Farel et al., 1991). The scale is valid through 12 months of age. Use of the scale requires that the observer be trained to achieve a level of concordance with a previously certified trainer. Other scales from the United States include the MacPhee (25 items), the Crittendon (81 items), and the Chatoor (46 items) (MacPhee et al., 1993). The more items, the better the scale discriminates between those with and without feeding difficulties.

In developing countries, a similar approach has been used. Guldan et al. (1993) in Bangladesh found a number of caregiver practices that differed according to the mother's education, adjusting for household education, wealth, child age, birth order, and gender. Variables associated with maternal education included some from each of the three categories defined earlier: adaptation to the child's psychomotor skills (number of finger food feedings per hour, child less likely to feed self, percent of time using cup, percentage of time using bottle), "responsiveness of the feeder" (noticing when food was dropped, whether mother initiated the feeding, caregiver less likely to be doing something else at the same time as breast-feeding); and the feeding situation (location, cleanliness, absence of distraction). Guldan et al. (1993, p. 925) conclude that more educated mothers adopted "more attentive feeding practices" and "more labor-intensive child care." Child behavior however was not assessed.

The Guldan et al. (1993) study found frequency of feeding to be associated with maternal education. This variable has appeared to be associated with child anthropometric status in several studies. Frequency of feeding, observed during continuous observations, was associated with child nutritional status for children 18-23 months of age in Kenya (Ricci et al., 1994).

Engle and Zeitlin (1996) observed 37 different items per eating event in Managua, Nicaragua, and constructed a scale for active feeding behavior of the caregiver and child demand from a subset of the items. Whereas child demand was positively associated with nutritional status, active feeding was not; rather, active feeding was associated with a child's lack of interest in food, suggesting that caregivers in 
this situation may feed actively in response to child refusal.

Bentley et al. $(1991,1992)$ developed a scoring system to measure child and caregiver behaviors for each food rather than for each eating event. Rather than assessing the presence or absence of specific behaviors, they constructed a Guttman scale for child behaviors and for caregiver behaviors. The assumption behind a Guttman scale is that there is a logical order among dichotomously coded items and that they tend to always appear in that order. Theoretically a scale based on a correct implicit ordering will be more predictive than a scale based on a simple sum, as in the Engle and Zeitlin (1996) study. For the child, the three-point scale was food refusal, food appetite, and food request. For the caregiver, the scale was no response, verbal encouragement, verbal pressure, and physical force. The scale illustrated that caregivers were more active feeders when the children were convalescing from diarrhea than when they were healthy (Bentley et al., 1991).

Quantitative assessments of feeding behaviors: This approach counts the number of instances, rather than the presence or absence, of a behavior during a feeding episode (Polan and Ward, 1994; Sanders et al., 1993; Klesges et al., 1986; Zeitlin, Houser and Johnson, 1989). If behaviors are relatively discrete, the number of instances of that behavior during a feeding episode, such as the number of times the mother touches the child, can be counted (Polan and Ward, 1994). Sanders et al. (1993) rated the frequency of 14 parent and 17 child behaviors using the Mealtime Observation Schedule in Australia. For behaviors varying in duration, one can code whether or not the behavior is occurring after a fixed interval (for example, every five minutes). Zeitlin, Houser and Johnson (1989) coded the presence of active feeding behaviors and child feeding behaviors every five seconds for Mexican infants. In each case, the measurement was able to differentiate between children who were growing well and those who were growing poorly.

Behavioral ratings: This technique rates the overall quality of the child-caregiver interaction. Black et al. (1994) have used it based on the coding scheme from the Parent Child Early Relation Assessment (PCERA) (Clark, 1985). The technique of behavioral ratings is widely used for the assessment of child behavior (for example, the Behavior Rating Scale from the
Bayley Scales for Infant Development; Bayley, 1993) in the United States and has been used in developing countries (Engle et al., 1996). A domain of behavior is defined (for example, "Parent reads child's cues and responds sensitively and appropriately"), it is carefully described in behavioral terms (for example, "This variable is composed of parent's ability to accurately observe the child's cues, to understand what the child needs and wants, and to demonstrate the capacity to respond appropriately"), with some behavioral descriptions ("for example, if an infant squirms, or shows discomfort in the way he or she is held, a parent adjusts holding position; if an older infant tugs at mother's skirt, she responds to the need for attention by touching, holding, etc.") (Black et al., 1994).

Ratings from trained coders have been found to discriminate between children growing well and not growing well in the United States (Black et al., 1994, 1995). One of the reasons for using a rating system rather than predefined codes is that the caregiver's overall style, rather than specific behaviors, may be a better predictor of child outcomes.

Structured situation challenge: Under the rubric of "social marketing," the Manoff Group has employed a strategy of presenting the caregiver with a challenge, such as a new food, and observing the caregiver's behavior to assess acceptability and potential problems with the introduction. Dickin, Griffiths and Piwoz (1997) explain the technique in great detail and the way it should be used. Although one could code each observation systematically, the authors have used it in a more qualitative manner, assessing whether the innovation was acceptable and what kinds of problems appeared to arise in the situation. Validity of the method was not assessed.

These measurement techniques are, of course, prone to methodological problems. Does the caregiver being observed exhibit typical behavior? One can argue that even if the caregiver's behavior is altered, she is probably demonstrating her notion of ideal behavior, which can be revealing. For example, Black et al. (1994) found that $40 \%$ of mothers of children with failure to thrive were observed to neglect their children (interacting rarely) in spite of being videotaped in a clinical setting, a behavior they might have felt was not ideal. There does appear to be evidence for the validity of these measures, since a number of studies have indicated that they can discrimi- 
nate between children with feeding difficulties and normally growing children (Heffer and Kelley, 1994). A second concern with these rather brief observations is their reliability over time (would the child and caregiver behave the same way on a different day?). Barnard et al. (1989) found consistencies in maternal feeding behaviors during the first year of life, but more research is needed in this area. A third concern is the generalizability of these behaviors to a different kind of behavior (for example, is a caregiver who is responsive to the child during feeding also responsive to the child during play?). Black et al. (1995) found that there was more variability in maternal control in the play situation than the feeding situation, probably because feeding behaviors are more constrained, but maternal nurturance was similar in the two settings.

Other problems include deciding on which behaviors to code, establishing the reliability of coding of the behaviors, defining the categories operationally, and deciding on the appropriate setting in which to evaluate the behavior. It is essential that observers be well trained and standardized in order for the assessment to have validity (meaning). For suggested measures, see Tables 8 and 9 .

\section{(vi) Psychosocial care}

Psychosocial care refers to the provision of affection and warmth, responsiveness to the child, and the encouragement of autonomy and exploration. In this area, as in no other, is the importance of culture central. As noted earlier in the section on culture, a universal perspective would suggest that the same function (for example, showing affection) may be demonstrated differently from one culture to another, and careful work with members of the cultural group is required to be sure that correct interpretations of behavior are made. For example, affection can be shown through physical, visual, and verbal contact with children. But, the patterns of expression may vary by culture. Becker and Becker (1994, p. 192) warn that "any given indicator of maternal attachment as derived in one racial group may not necessarily be valid in other racial groups."

\section{(vii) Measurement of psychosocial care}

Three categories of measures of psychosocial care can be described: direct measurement of child-caregiver interaction, assessment of the home environment, and assessment of the child's appearance.
Observations of child-caregiver interaction: Typically, the frequency of caregiver behaviors, child behaviors, and child-caregiver interaction patterns are coded (Rahmanifar et al., 1992). Behaviors most often assessed are verbalizations of child and caregiver and looking and touching, although these behaviors will vary with the age of the child. A second technique is to present the caregiver with a task, such as asking her to play with a specific toy with the child, and then rate her behavior on a checklist (Barnard et al., 1989) or count the number of times an event occurs. Several studies suggest two child risk factors: a child is inactive ("doing nothing") a high percentage of the time, and a child is carried and held excessively after 18 months. High rates of holding and carrying of children beyond 18 months has been negatively associated with cognitive development and social interactions with other children (Wachs et al., 1991; Sigman et al., 1989), both because the holding and carrying restricts the opportunities for learning and because children who choose to be held tend to be lighter and are more likely to be ill (Sigman et al., 1989).

Assessment of the home environment: The most commonly used global assessment of the living situation is the Home Observation for Measurement of the Environment (HOME) scale. Using this scale in an interview with the caregiver, both the environment and incidence of positive effect between caregiver and child are rated (Bradley and Caldwell, 1984). The HOME scale assesses both the emotional responsiveness of the caregiver and the characteristics of the environment that are supportive of autonomy and exploration by the child (including avoidance of punishment, provision of appropriate play materials or location, opportunities for variety in daily stimulation, and organization of the physical and temporal environment). It has been adapted and used in many countries and has had consistent positive associations with cognitive development in a variety of settings (Bradley and Caldwell, 1984; Bradley et al., 1989), in addition to controlling for the effects of socioeconomic status. For suggested measures, see Tables 10 and 11.

\section{CONCLUSIONS AND AREAS FOR FURTHER RESEARCH}

Meeting the needs of the hungry and addressing the problems of malnutrition 
Table 11. Psychosocial care: Child variables

\begin{tabular}{lcc}
\hline Construct & Measurement tools & Comment \\
\hline $\begin{array}{l}\text { Alertness or } \\
\text { drowsiness } \\
\text { Verbalization }\end{array}$ & $\begin{array}{c}\text { Brazelton Assessment Scale for new-borns; } \\
\text { observations of child behavior } \\
\text { Count verbalizations } \\
\text { during observation } \\
\begin{array}{l}\text { Rate of motor and } \\
\text { mental development }\end{array}\end{array}$ & $\begin{array}{c}\text { More caregiver interaction with } \\
\text { more alert children } \\
\text { Measurement depends on } \\
\text { age of child }\end{array}$ \\
$\begin{array}{l}\text { Physical health or } \\
\text { disability status }\end{array}$ & $\begin{array}{c}\text { Tebstion } \\
\text { clinical observation }\end{array}$ & $\begin{array}{c}\text { Earlier achievement of motor } \\
\text { development associated with } \\
\text { cognitive development } \\
\text { Depends on particular } \\
\text { disability }\end{array}$ \\
\hline
\end{tabular}

requires an understanding of each step in the process from seed in the ground to food in the mouth. The first steps in this process have received the most attention. This paper, however, is concerned with conceptual developments in the last stage of the process: how the various aspects of care of young children affect their nutrient intake and their nutritional status. As it becomes increasingly accepted that many activities in child care-feeding practices, food preparation and storage, hygiene, access to health care, and psychosocial stimulationcontribute to good nutrition for the child, ways to measure the adequacy of care must be developed. This report has reviewed the UNICEF conceptual framework, two care practices, feeding and psychosocial care, and resources for care and their importance for child nutrition. From the literature reviewed, some conclusions can be made regarding resources for care, the effects of the child on care provision, the measurement of care, and research needs.

(a) Resources for care: Human, economic, and organizational

\section{(i) Education, knowledge, and beliefs}

Education of the mother is often associated with a greater commitment to care of the child. Educated women tend to provide better home health care and hygiene, and they are more likely to seek help when a child is ill. But, on the negative side, better-educated women in developing countries tend to terminate breast-feeding earlier.

(ii) Health and nutritional status of the caregiver

Many women in developing countries are chronically ill or undernourished. Studies show that lack of iron decreases productivity, and $60 \%$ of women in South Asia have iron-defi- ciency anemia. Although a direct link between caregiver nutritional status and quality of care has not been studied extensively, patterns indicate that women care for their children less during periods of food shortages, perhaps because they must spend more time looking for food and because their energy levels are low.

(iii) Mental health, lack of stress, and self-confidence of the caregiver

A large body of literature links maternal depression and stress with poor caregiving in the developed countries, but few studies to establish this connection have been done in developing countries. Measures of depression and stress should be developed that are tailored to the developing countries, since the methods that have been used may not be appropriate across cultures.

(iv) Autonomy, control of resources, and intrahousehold allocation

Studies have shown that when women control household resources, they tend to allocate larger amounts of resources such as food to children than when men are in control. Working for income does not always mean that a woman has control of income.

\section{(v) Workload and time constraints}

According to the literature, women spend more time than men in all work activities. In addition to child care, women often must gather wood, carry water, prepare food, and do farmwork or other productive work. The effects on child nutrition are not straightforward: some studies suggest that when women work outside the home, even on their own farms, their children are more likely to be malnourished, especially if they do not control income or if a child is under one year old. Other studies have found no negative effects from mothers' 
working, and some have found positive effects when mothers' work was well paid.

\section{(vi) Social support received by the caregiver}

Provision of competent alternate child care is one important type of social support. Institutional care is seldom available in developing countries. The increased entry of women into the labor force without adequate child care support is cause for concern. Surprisingly little is known about alternate caregivers - who they are, their capacity for providing care, and how caregiving instructions are transmitted from the primary caregiver to the alternate. Provision of care to young children comes at a high cost if it means that older girls are kept out of school to act as alternate caregivers. Supporting and developing the role of men as fathers has seldom received attention in developing-country studies and may have potential for improving the life of children and women.

\section{(b) Effects of the child on care provision}

The UNICEF conceptual framework for child survival, growth, and development is a useful framework for evaluating care practices and resources for care, as well as health services and the environment, and food security. The model recognizes not only the importance of the caregiver's behavior in determining child outcomes, but also the role of child characteristics and the match between characteristics and environment in these outcomes. All three of these factors play a significant role in the child's survival, growth, and development.

Responsiveness of the caregiver to the child's communication signals (words, gestures, cries) is a critical dimension of caregiving. The unresponsive child may have a difficult time eliciting a response from the caregiver. Studies have shown that children who are larger and better nourished may receive more care than lowbirth-weight children. Poorly nourished children may be more lethargic and may therefore not encourage caregivers to respond to them. The child with low appetite who refuses food or is difficult to feed may discourage caregivers from persisting in feeding long enough for the child to consume an adequate amount of food. Inadequate interaction between caregiver and child often lies behind the problem of a child who fails to thrive. In sum, a positive relationship between caregiver and child may lead to increased dietary intake.

\section{(c) Measuring care}

This paper describes steps in the process of measuring care: defining a construct theoretically, developing valid measurements, and defining levels of the indicators of risk. For example, a child's nutritional status can be conceptualized as adequate stature or physical growth according to internationally recognized norms, and adequate micronutrient status. A child's height- and weight-for-age have been defined as valid measurements, and a risk indicator is falling two standard deviations below the mean for height-for-age, using recognized (NCHS) norms.

Total time spent per day on child care is not an adequate indicator of care. Time estimates should be carefully defined in terms of type of activity, such as supervision or feeding. They should be complemented by measurements of specific activities performed, and quality of child care. Quality determinations are not easy to make because cultural differences in the definition of appropriate care practices and resources are substantial. It may be possible however to measure quality of care indirectly, such as through age of alternate caregivers, physical status of caregivers, or self-esteem of caregivers.

Measurement tools for assessing care include questionnaires or interviews, qualitative scales for assessing practices, systematic observations in the care setting, a "structured situation challenge" followed by observation, and detailed coding of ongoing sequences of interactions. For example, feeding behaviors of caregivers and children might be evaluated by observing a feeding session and rating behavior based on a list of items, or rating of the overall quality of interaction between the caregiver and child. Frequency of feeding can be observed over a period of time. A "structured situation challenge" could be created by providing a new food and observing how the caregiver and child handle the situation.

In measuring the psychosocial elements of care provision, it is crucial to keep in mind that affection and responsiveness can be shown through physical, visual, and verbal contact: the patterns of expression vary from one culture to another. A behavior that may appear strange to an outsider may be the norm in a particular culture; therefore, it is important to compare a caregiver with others in his or her own culture, and to elicit cultural explanations for behaviors. 
There is not enough evidence at this point to suggest specific indicators that should be used for risk assessment, particularly across cultures and contexts. Much work needs to be done to clarify these measures and to develop a body of research on caregivers' resources in a wide range of cultures. Studies on maternal education and beliefs and mothers' use of time in developing countries are plentiful. Little has been done, however, on the effects of mothers' nutritional status on the nutrition of the child, nor on the effects of mothers' self-esteem and confidence, stress, and possible depression on child care, although these factors are probably significant constraints to care provision. The potential for improving the provision of care through more research and intervention in these two areas seems promising.

\section{(d) Setting priorities}

How can one decide which among the care practices and resources for care might be most effective for intervention? The answer will depend on each situation. One approach is to rate each care practice and resource in terms of two criteria: Importance of the practice or resource for child nutritional status, and feasibility of change. The practice or resource that appears to be both important and feasible for change can then be given priority. Murray et al. (1998), in their discussion of 16 "emphasis behaviors" for maternal and child health, describe a process of setting priorities through assessing (i) feasibility of changing behavior, (ii) resources available to implement the program, and (iii) local capacity to implement the program. Relying on existing data to understand the limitations on good nutrition can be helpful.

A second criterion is to target practices or resources that have received relatively little attention, such as father's role, for investigation.

A broader question concerns the relative benefit of trying to support changes in care practices or to strengthen resources for care through women's empowerment or skill development. As with other items, this decision will depend on the context and limiting factors. In some situations, women's status may be so low that it is an obvious target for action. In others, women's status may be adequate, and food may be available, but practices regarding feeding or breast-feeding may be deficient. A careful analysis using this framework may be helpful.

In the United States a number of studies of the effectiveness of various early intervention approaches for children's development have compared the relative costs and benefits of investing in women themselves as opposed to providing improved care directly to children (see summary in Pelto, Dickin and Engle, 1999). Results suggested that whereas provision of direct services to children through enrolling them in high-quality child care centers creates the greatest impact, support for the mother may have long-term effects that carry over to the next generation and may be more cost-effective. In general, the most cost-effective approach is to combine support and enhancement of the mother's resources for care in addition to teaching specific care practices. With respect to care practices and resources for nutrition, future research may provide similar answers.

\section{NOTES}

1. Throughout this paper, the term "caregiver" is used rather than "mother." Most of the time, the caregiver is the mother, but other females in the household also provide care. In virtually every culture, women are the primary providers of food, as well as the primary caregivers for children (Rogers and Youssef, 1988, p. 33). It is usually women who shop, prepare, and distribute the food for family meals, and women who provide the basic nurturing and caregiving activities for children, such as feeding, cleaning, dressing, attending to illnesses, and keeping a watchful eye on the children's activities. As the classic paper by Weisner and Gallimore (1977) illustrates, in many cultures, siblings (primarily females) begin to be major caregivers when children are beyond one or two years of age. Women's time spent on direct child care has been found to decline precipitously as a child moves from breast-feeding and infancy to walking during the second year of life (Ho, 1979; Cassidy, 1987), although they may continue to supervise the care. When infants are ill, older female siblings may increase time spent on child care (Pitt and Rosenzweig, 1990). When women are employed, care may be provided by others without supervision. Men also provide some care, although it tends to be holding and carrying rather than physical care (Engle and Breaux, 1998). In Nepal, $25 \%$ of care for children $0-5$ years was 
provided by adult males (Paolisso and Regmi, 1995). In Pakistan, men traditionally shop for food and are more likely to carry and hold infants in public than are women (Jahn and Aslam, 1995). Thus, it is necessary to broaden the focus beyond the mother in order to include all resources for care, whether provided by siblings, older relatives, the father, or institutions such as child care centers.

2. Care differs from caring capacity because "capacity" refers to a potential to provide care, but it may not indicate whether the care is provided. If the caregiver has many constraints to care, she may not be able to put her capacity into practice. A second commonly used term that seems to overlap with care is "infant and young child feeding practices." But feeding practices, which are usually assessed by interviewing the mother, may reflect overall patterns of behavior rather than specific actions. What people actually do, on the other hand, may or may not be consistent with these general patterns of behavior. For example, a woman may state that she introduced complementary feeding to a child at four months of age and forget the small bites offered to a curious child at three months because they did not seem to be significant events and were not encoded in her memory as foods offered. If she thinks that her overall decision was to introduce complementary food at four months, the small bites earlier may be inconsistent with her overall pattern and therefore not remembered. Thus the reported infant feeding practice represents a simplification of practices consistent with belief, but not necessarily an accurate reflection of day-to-day practices. Both practices and behavior are important to evaluate, but the difference between them should be recognized.

3. See Engle and Ricciuti (1995) for a summary of this argument.

4. A construct is "a concept used in a particular theoretical manner that ties together a number of observations." It cannot be observed directly but, like gravity or evolution, is indirectly inferred from data (Ray, 1997, p. 22).
5. In attempting to statistically estimate the impact of education on the level of caring behaviors exhibited, it will be important to take into account unobserved factors that could contribute to both the level of care and the level of education. Failure to take into account such factors (such as concern for child well-being) could lead to biased estimates of the impact of education on care.

6. Shetty and James (1994) cite unpublished FAO data provided in a personal communication by $\mathrm{P}$. J. Françoise in 1990.

7. B vitamin deficiencies and deficiencies of iron, zinc, and vitamin A often cluster in poor families; the fact that $\mathrm{B}$ vitamin deficiencies were mentioned depended in part on the dietary quality measures chosen to assess. Dietary deficiencies are most common in conditions of poverty.

8. See, for example, Chakraborty (1990) on Calcutta.

9. Women's involvement in economic activities in the developing countries varies widely by region, from a high of 56 to $58 \%$ in eastern and central Asia, to 53 to $54 \%$ in sub-Saharan Africa and southeastern Asia, $50 \%$ in the Caribbean and Oceania, about $30 \%$ in Latin America and western Asia, and 21\% in northern Africa. Over the past two decades, men's economic activity rates have declined, whereas women's have increased substantially in all regions except sub-Saharan Africa and eastern Asia, where they were already high (United Nations, 1995). Work rates are higher for rural than for urban women in all parts of the world except for Latin America, where most of the rural work tends to be agricultural and seasonal, but possibly requiring fewer hours per day. Women in Guatemala who reported doing agricultural work were working, on average, only an hour a day (Engle, 1989a).

10. One example is the Iringa, Tanzania, program sponsored by UNICEF (1989).

\section{REFERENCES}

Abbi, R., Christian, P., Gujral, S. and Gopaldas, T. (1991) The impact of maternal work status on the nutrition and health status of children. Food and Nutrition Bulletin 13 (1), 20-25.

Adair, L. S. and Popkin, B. M. (1996) Low birth weight reduces likelihood of breast-feeding among Filipino infants. Journal of Nutrition 126 (January), 103-111.

Adair, L. S., Popkin, B. M. and Guilkey, D. K. (1993) The duration of breast-feeding: How is it affected by sociodemographic, health sector, and food industry factors? Demography 30 (1), 63-80.

AED (Academy for Educational Development) (1995) Final report: Mali nutrition communication project 1989-1995. AED, Washington, DC.

Ainsworth, M. D. S., Blehar, M. C., Waters, E. and Wall, S. (1978) Patterns of Attachment: A Psychological Study of the Strange Situation. Erlbaum, Hillsdale, NJ 
Allen, L. H., Backstrand, J. R., Chávez, A. and Pelto, G. H. (1992) People cannot live by tortillas alone: The results of the Mexico Nutrition CRSP. Final Report to the US Agency for International Development, USAID, Washington, DC.

Almedom, A. M. (1991a) Infant feeding in urban lowincome households in Ethiopia: I. The weaning process. Ecology of Food and Nutrition 25 (2), 97109.

Almedom, A. M. (1991b) Infant feeding in urban lowincome households in Ethiopia: II: Determinants of weaning. Ecology of Food and Nutrition 25 (2), 111 121.

Baksh, M., Neumann, C. G., Paolisso, M., Trostle, R. M. and Jansen, A. A. J. (1994) The influence of reproductive status on rural Kenyan women's time use. Social Science and Medicine 39 (3), 345-354.

Barnard, K. E., Hammond, M. A., Booth, C. L., Bee, H. L., Mitchell, S. K. and Spieker, S. J. (1989) Measurement and meaning of parent-child interaction. In Applied Developmental Psychology, Vol. 3, ed. F. Morrison, C. Lord, and D. Keating. Academic Press, San Diego, CA.

Barrera, A. (1990) The role of maternal schooling and its interaction with public health programs in child health production. Journal of Developmental Economics 32 (1), 69-91.

Bayley, N. (1993) Bayley Scales of Infant Development: Second Edition Manual. The Psychological Corporation, San Antonio, TX.

Becker, G. and Becker, C. (1994) The maternal behavior inventory: Measuring the behavioral side of motherto-infant attachment. Social Behavior and Personality 22 (2), 177-194.

Bell, R. Q. (1971) Stimulus control of parent or caretaker behavior by offspring. Developmental Psychology 4, 63.

Bentley, M. E., Black, M. M. and Hurtado, E. (1995) Child-feeding and appetite: What can programmes do? Food and Nutrition Bulletin 16 (4), 340-349.

Bentley, M. E., Stallings, R. Y., Fukumoto, M. and Elder, J. A. (1991) Maternal feeding behavior and child acceptance of food during diarrhea, convalescence, and health in the central Sierra of Peru. American Journal of Public Health 81 (1), 43-47.

Bentley, M. E., Caulfield, L. E., Torun, B., Schroeder, D. and Hurtado, E. (1992) Maternal feeding behavior and child appetite during acute diarrheal episodes and subsequent child health in Guatemala. FASEB (Federation of American Societies of Experimental Biology) Journal 6, A1648.

Bernard, H. R., Killworth, P. D. and Salier, L. (1984) The problem of informant accuracy: The validity of retrospective data. Annual Review of Anthropology 13, 495-517.

Berry, J. W., Poortinga, Y. H., Segall, M. H. and Dasen, P. R. (1992) Crosscultural Psychology. Cambridge University Press, Cambridge.

Best, J. B. (1989) Cognitive Psychology. West Publishing, St. Paul, MN.

Black, M. M. (1995) Failure to thrive: Strategies for evaluation and intervention. School Psychology Review 24 (2), 171-185.
Black, M. M. and Teti, L. (1997) Videotape: A culturally sensitive strategy to promote communication and healthy nutrition between adolescent mothers and infants. University of Maryland School of Medicine, Baltimore, MD.

Black, M. M., Hutcheson, J. J., Dubowitz, H. and Berenson-Howard, J. (1994) Parenting style and developmental status among children with nonorganic failure to thrive. Journal of Pediatric Psychology 19 (6), 689-707.

Black, M. M., Dubowitz, H., Hutcheson, J. J., Berenson-Howard, J. and Starr, R. H. (1995) A randomized clinical trial of home intervention for children with failure to thrive. Pediatrics 95 (6), 807-813.

Blau, D. M., Guilkey, D. K. and Popkin, B. M. (1996) Infant health and the labor supply of mothers. Journal of Human Resources 31 (1), 90-139.

Blumberg, R. L. (1988) Income under female versus male control. Journal of Family Issues 9, 51-84.

Bradley, R. H. and Caldwell, B. M. (1984) 174 children: A study of the relationship between home environment and cognitive development during the first 5 years. In Home Environment and Early Cognitive Development, ed. A.W. Gottfried. Academic Press, Orlando, FL.

Bradley, R. H., Caldwell, B. M., Rock, S. L., Barnard, K. E., Gray, C., Hammond, M. A., Mitchell, S., Siegel, L., Ramey, C. T., Gottfried, A. W. and Johnson, D. L. (1989) Home environment and cognitive development in the first three years of life: A collaborative study involving six sites and three ethnic groups in North America. Developmental Psychology 25, 217-235.

Bronstein, M. H. (1991) Cultural Approaches to Parenting. LEA, Hillsdale, NJ.

Brown, K. H., Dickin, K. L., Bentley, M. E., Oni, G. A., Obassaju, V.T., Esrey, S. A., Mebrahtu, S., Alade, I. and Stallings, R. Y. (1988) Consumption of weaning foods from fermented cereals in Kwara State, Nigeria. In Improving Young Child Feeding in Eastern and Southern Africa Household-level Food Technology, ed. D. Alnwick, S. Moses, and O. G. Schmidt. Proceedings of a workshop held in Nairobi, Kenya, October 12, 1987. International Development Research Centre, Ottawa, Canada.

Brown, L. R. and Haddad, L. (1995) Time allocation patterns and time burdens: A gendered analysis of seven countries. International Food Policy Research Institute, Washington, DC.

Brown, L. R., Yohannes, Y. and Webb, P. (1994) Rural labor-intensive public works: Impacts of participation on preschooler nutrition. Evidence from Niger. American Journal of Agricultural Economics 76 (5), 1213-1218.

Bruce, J., Lloyd, C. B. and Leonard, A., with Engle, P. L. and Duffy, N. (1995) Families in Focus: New Perspectives on Mothers, Fathers, and Children. The Population Council, New York.

Cassidy, C. M. (1987) World-view conflict and toddler malnutrition: Change agent dilemmas. In Child Survival, ed. N. Scheper-Hughes. D. Reidel, Dodrecht, The Netherlands. 
Castle, S. E. (1995) Child fostering and children's nutritional outcomes in rural Mali: The role of female status in directing child transfers. Social Science and Medicine 40 (5), 679-693.

Cebu Study Team (1991) Underlying and proximate determinants of child health: The Cebu Longitudinal Health and Nutrition Study. American Journal of Epidemiology 133 (2), 185-201.

Chakraborty, A. (1990) Social Stress and Mental Health: A Social-Psychiatric Field Study of Calcutta. Sage, New Delhi.

Clark, R. (1985) The Parent-Child Early Relational Assessment: Instrument and Manual. University of Wisconsin Medical School, Department of Psychiatry, Madison, WI.

Cominsky, S., Mhloyi, M. and Ewbank, D. (1993) Child feeding practices in a rural area of Zimbabwe. Social Science and Medicine 36 (7), 937-947.

Coopersmith, D. (1981) Self-Esteem Inventories. Consulting Psychologists Press, Palo Alto, CA.

DaVanzo, J. and Starbird, E. H. (1991) Correlates of short interbirth intervals in peninsular Malaysia: Their pathways of influence through breast-feeding and contraceptive use. Studies in Family Planning 22 (4), 241-254

de Groote, H., Kennedy, E., Payongayong, E. and Haddad, L. (1994) Credit with education for women in Mali: Impacts on income, food security, and nutrition. Report to the U.S. Agency for International Development. International Food Policy Research Institute, Washington, DC.

de Onis, M., Villar, J. and Gülmezoglu, M. (1998) Nutritional interventions to prevent intrauterine growth retardation: Evidence from randomized controlled trails. European Journal of Clinical Nutrition 52 (S1), S83-S91.

Dettwyler, K. A. (1986) Infant feeding in Mali, West Africa: Variations in belief and practice. Social Science and Medicine 23 (7), 651-664.

Dettwyler, K. A. (1987) Breast-feeding and weaning in Mali: Cultural context and hard data. Social Science and Medicine 24 (8), 633-644.

Dickin, K., Griffiths, M. and Piwoz, E. (1997) Guide to TIPS. Manoff Foundation, Washington, DC.

Doan, R. M. and Bisharat, L. (1990) Female autonomy and children's nutritional status: The extended family residential unit in Amman, Jordan. Social Science and Medicine 31 (7), 783.

Doan, R. M. and Popkin, B. M. (1993) Women's work and infant care in the Philippines. Social Science and Medicine 36 (3), 297-304

Dohrenwend, B. P. and Dohrenwend, B. S. (1974) Psychiatric disorders in urban settings. In American Handbook of Psychology, 2nd ed., Vol. 29, ed. S. Arieti. Basic Books, New York.

Drotar, D., Eckerle, D., Satola, J., Pallotta, J. and Wyatt, B. (1990) Maternal interactional behavior with non-organic failure-to-thrive infants: A case comparison study. Child Abuse and Neglect 14 (1), 41-51.

Engle, P. L. (1989a) Child care strategies of working and nonworking women in rural and urban Guatemala. In Women's Work and Child Welfare in the Third
World, ed. M. Paolisso and M. Buvinic. Westview, Boulder, Co.

Engle, P. L. (1989b) Mothers' income control: Consequences for mothers and their children. Paper presented at the Association for Women in Development, Washington, DC.

Engle, P. L. (1991) Maternal work for earnings and child care strategies: Nutritional effects. Child Development 62, 954-965.

Engle, P. L. (1992) Care and child nutrition. Theme paper for the International Conference on Nutrition (ICN), Rome. Paper prepared for the Nutrition Section, UNICEF, New York.

Engle, P. L. (1993) Influences of mother's and father's income on children's nutritional status in Guatemala. Social Science and Medicine 37 (11), 1303-1312.

Engle, P. L. (1995) Mothers' money, fathers' money, and parental commitment: Guatemala and Nicaragua. In Engendering Wealth and Well-Being, ed. R. Blumberg, C. A. Rakowski, I. Tinker, and M. Monteon. Westview, Boulder, Co.

Engle, P. L. and Breaux, C. (1998) Fathers' responsibility for children: A cross-cultural perspective. Social Policy Report of the Society for Research in Child Development 12 (1), 1-23.

Engle, P. L. and Lumpkin, J. B. (1992) How accurate are time-use reports? Effects of cognitive enhancement and cultural differences on recall accuracy. Applied Cognitive Psychology 6, 141-159.

Engle, P. L. and Ricciuti, H. N. (1995) Psychosocial aspects of care and nutrition. Food and Nutrition Bulletin 16 (4), 356-377.

Engle, P. L. and Zeitlin, M. F. (1996) Active feeding behavior compensates for low interest in food among young Nicaraguan children. Journal of Nutrition 126 (July), 1808-1816.

Engle, P. L., Castle, S. E. and Menon, P. (1996) Child development: Vulnerability and resilience. Social Science and Medicine 43 (5), 621-635.

Engle, P. L., Hurtado, E. and Ruel, M. (1997) Smoke exposure of women and young children in highland Guatemala: Prediction and recall accuracy. Human Organization 56 (4), 408-417.

Engle, P. L., Lhotska, L. and Armstrong, H. (1997) The Care Initiative: Guidelines for Analysis, Assessment, and Action to Improve Nutrition. UNICEF, New York.

Engle, P. L., Zeitlin, M. F., Medrano, Y. and Moran, L. (1995) Parental theories about feeding Nicaraguan one-year-olds at risk of undernutrition. In Parents, Cultural Belief Systems, ed. S. Harkness and C. Super. Guilford, New York.

Engle, P. L., Vas Dias, T., Romero-Abal, J., Juan de Serrano, J., Bulux, J., Solomans, N. W. and Dewey, K. (1996) Effects of discontinuing coffee intake on cognitive development of Guatemalan toddlers: A randomized intervention study. FASEB [Federation of American Societies for Experimental Biology] Journal 10 (3), Abs. 1409.

Ever-Hadani, P., Seidman, D. S., Manor, O. and Harlap, S. (1994) Breast-feeding in Israel: Maternal factors associated with choice and duration. Journal of Epidemiology and Community Health 48 (3), 281-285. 
Farel, A. M., Freeman, V. A., Keenan, N. L. and Huber, C. J. (1991) Interaction between high-risk infants and their mothers: The NCAST as an assessment tool. Research in Nursing and Health $\mathbf{1 4}$ (2), 109-118.

Ferro-Luzzi, A., Sette, S., Franklin, M. and James, W. P. T. (1992) A simplified approach to assessing adult chronic energy deficiency. European Journal of Clinical Nutrition 46 (3), 173-186.

Finkelhor, D. and Dziuba-Leatherman, J. (1994) Victimization of children. American Psychologist 49 (3), 173-183.

Gerlach, L. P. (1964) Sociocultural factors affecting the diet of the northeast coastal Bantu. Journal of the American Dietetic Association 45, 420-424.

Gibbons, G. and Griffiths, M. (1984) Program activities for improving weaning practices. Report prepared for UNICEF. American Public Health Association, Washington, DC.

Giugliani, E. R. J., Issler, R. M. S., Justo, E. B., Seffrin, C. F., Hartman, R. M. and Carvalho, N. M. (1992) Risk factors for early termination of breast-feeding in Brazil. Acta Paediatrica 81 (6), 484-487.

Griffiths, M. (1988) Maternal self-confidence and child well-being. Paper presented at the annual meeting of the Society for Applied Anthropology, Tampa, FL, April 20-24.

Gryboski, K. L. (1996) Maternal and nonmaternal time allocation to infant care, and infant care during illness in rural Java, Indonesia. Social Science and Medicine 43 (2), 209-219.

Guldan, G. S., Zeitlin, M. F., Beiser, A. S., Super, C. M., Gershoff, S. N. and Datta, S. (1993) Maternal education and child feeding practices in rural Bangladesh. Social Science and Medicine 36 (7), 925-935.

Gülmezoglu, M., de Onis, M. and Villar, J. (1997) Effectiveness of interventions to prevent or treat impaired fetal growth. Obstetrical and Gynecological Survey 52, 139-149.

Haddad, L. (1992) The impact of women's employment status on household food security at different income levels in Ghana. Food and Nutrition Bulletin 14 (4), $34-44$.

Haddad, L. and Hoddinott, J. (1994) Women's income and boy-girl anthropometric status in the Côte d'Ivoire. World Development 22 (4), 543-553.

Harrison, G. G., Zaghloul, S. S., Galal, O. M. and Gabr, A. (1993) Breast-feeding and weaning in a poor urban neighborhood in Cairo, Egypt: Maternal beliefs and perceptions. Social Science and Medicine 36 (8), 1063-1069.

Heffer, R. W. and Kelley, M. L. (1994) Non-organic failure to thrive: Developmental outcomes and psychosocial assessment and intervention issues. Research in Development Disabilities 15 (4), 247-268.

Heise, L., Pitanguy, J. and Germain, A. (1994) Violence Against Women: The Hidden Health Burden. World Bank Population, Health, and Nutrition Discussion Paper. World Bank, Washington, DC.

Ho, T. (1979) Time costs of child-rearing in the Philippines. Population and Development Review 5 (4), 643-662.
Immink, M., Kennedy, E., Sibrian, R. and Hahn, H. (1994) Food availability, water and sanitation, and women's time constraints as risk factors of poor health and growth failure of children in the Central Highlands of Guatemala. International Food Policy Research Institute, Washington, DC.

ICN (International Conference on Nutrition) (1992) Plan of Action for Nutrition. ICN, Rome.

Jahn, A. and Aslam, A. (1995) Fathers' perceptions of child health: A case study in a squatter settlement of Karachi, Pakistan. Health Transition Review 5 (2), 191-206.

Joekes, S. (1989) Women's work and social support for child care in the Third World. In Women, Work, and Child Welfare in the Third World, ed. J. Leslie and M. Paolisso. Westview Press, Boulder, Co.

Johnson, F. C. and Rogers, B. L. (1993) Children's nutritional status in female-headed households in the Dominican Republic. Social Science and Medicine 37 (11), 1293.

Jonsson, U. (1995) Ethics and child nutrition. Food and Nutrition Bulletin 16 (4), 293-298.

Joshi, A. R. (1994) Maternal schooling and child health: A preliminary analysis of the intervening mechanisms in rural Nepal. Health Transition Review 4 (1), $1-26$.

Kennedy, E. and Peters, P. (1992) Household food security and child nutrition: The interaction of income and gender of household head. World Development 20 (8), 1077-1085.

Kirksey, A., Harrison, G. G., Galal, O. M., McCabe, G. P., Wachs, T. D. and Rahmanifar, A. (1992) The human costs of moderate malnutrition in an Egyptian village. Final report to the US Agency for International Development, USAID, Washington, DC.

Kirksey, A., Wachs, T. D., Yunis, F., Srinath, U., Rahmanifar, A., McCabe, G. P., Galal, O. M., Harrison, G. G. and Jerome, N. W. (1994) Relation of maternal zinc nutritive to pregnancy outcome and infant development in an Egyptian village. American Journal of Clinical Nutrition 60 (5), 782792.

Klesges, R. C., Malott, J. M., Boschee, P. F. and Weber, J. M. (1986) The effects of parental influences on children's food intake, physical activity, and relative weight. International Journal of Eating Disorders 5 (2), 335-346.

Kotchabhakdi, N. J., Winichagoon, P., Smitasiri, S., Dhanamitta, S. and Valyasevi, A. (1987) The integration of psychosocial components of early childhood development in a nutrition education programme of Northeast Thailand. Paper prepared for the Third Inter-Agency meeting of the Consultative Group on Early Childhood Care and Development, Washington, DC.

Kraus, S. J. (1991) Attitudes and the prediction of behavior. PhD dissertation, Harvard University, Cambridge, MA.

Kurz, K. and Ngo Som, J. (1994) Study of the factors that influence the nutritional status of adolescent girls in Cameroon. Nutrition of Adolescent Girls Research Program, Research Report Series No. 10, Interna- 
tional Center for Research on Women, Washington, DC.

LaMontagne, J., Engle, P. L. and Zeitlin, M. (1998) Maternal employment and nutritional status of 12 18 month old children in Managua, Nicaragua. Social Science and Medicine 46 (3), 403-414.

Launer, L. J. and Habicht, J.-P. (1989) Concepts about infant health, growth, and weaning: A comparison between nutritional scientists and Madurese mothers. Social Science and Medicine 29 (1), 13-22.

Leonard, A. and Landers, C. (1992) Working women and the need for child care: Opportunities for programmatic collaboration. Report prepared by the Consultative Group on Early Childhood Care and Development, UNICEF, New York.

Leslie, J. (1988) Women's work and child nutrition in the Third World. World Development 16 (11), 13411362.

Leslie, J. (1989) Women's work and child nutrition in the Third World. In Women, Work, and Child Welfare in the Third World, ed. J. Leslie and M. Paolisso. Westview Press, Boulder, Co.

LeVine, R. A., LeVine, S. E., Richman, A., Uribe, F. M. T., Sunderland-Correa, C. and Miller, P. M. (1991) Women's schooling and child care in the demographic transition: A Mexican case study. Population and Development Review 17 (3), 459-496.

MacPhee, M., Haynes-Seman, C., Schneider, J. and Mullen, B. (1993) Dyadic synchrony in failure-tothrive. Paper presented at the annual meeting of the Society for Research in Child Development, Kansas City, MO.

Mansbach, I. K., Greenbaum, C. W. and Sulkes, J. (1991) Onset and duration of breast-feeding among Israeli mothers: Relationships with smoking and type of delivery. Social Science and Medicine 33 (12), 1391-1397.

McCullough, A. L., Kirksey, A., Wachs, T. D., McCabe, G. P., Bassily, N. S., Bishry, Z., Galal, O. M., Harrison, G. G. and Jerome, N. G. (1990) Vitamin B6 status of Egyptian mothers: Relation to infant behavior and maternal-infant interactions. American Journal of Clinical Nutrition 51, 1067-1074.

McDonald, M. A., Sigman, M., Espinosa, M. P. and Neumann, C. G. (1994) Impact of a temporary food shortage on children and their mothers. Child Development 65 (2), 404-415.

McGuire, J. and Popkin, B. M. (1989) Beating the zerosum game: Women and nutrition in the Third World. Part 1. Food and Nutrition Bulletin 11 (4), 38-63.

McGuire, J. and Popkin, B. M. (1990a) Beating the zerosum game: Women and nutrition in the Third World. Part 2. Food and Nutrition Bulletin 12 (1), 3-11.

McGuire, J. and Popkin, B. M. (1990b) Helping Women Improve Nutrition in a Developing World: Beating the Zero Sum Game. World Bank Technical Paper Number 114, World Bank, Washington, DC.

Merchant, K., Martorell, R., Gonzales-Cossio, T., Rivera, J. and Haas, J. (1989) Maternal Nutritional Depletion: Evidence of Responses in Women to Frequent Reproductive Cycling. Maternal Nutrition and Health Care Program Research Report No. 3,
International Center for Research on Women, Washington, DC.

Milla, P. J. (1991) Feeding, tasting, and sucking. In Pediatric Gastrointestinal Disease, ed. W.A. Walker et al. B.C. Decker, Philadelphia, PA.

Morley, D., Rohde, J. E. and Williams, G. (1983) Practising Health for All. Oxford University Press, Oxford.

Mull, D. (1991) Traditional perceptions of marasmus in Pakistan. Social Science and Medicine 32 (2), 175191.

Murray, J., Adeyi, G. N., Graeff, J., Fields, R., Rasmuson, M., Salgadom, M. and Sanghri, T. (1998) Emphasis behaviors in maternal and child health: Focusing on caretaker behaviors to develop maternal and child health programs in communities. Technical report, Basics, Washington, DC.

Neumann, C. G., Bwibo, N. O., Marquardt, M., Trostle, M. and Wienberg, S. (1994) Food intake during acute illness and convalescence in Kenyan toddlers. FASEB [Federation of American Societies for Experimental Biology] Journal 8 (4), A 2550.

Nsamenang, B. A. (1992) Perceptions of Parenting among the NSO of Cameroon. Father-Child Relations: Cultural and Biosocial Contexts. Aldine de Gruyter, New York.

Onyango, A., Tucker, K. and Eisemon, T. (1994) Household headship and child nutrition: A case study in western Kenya. Social Science and Medicine 39 (12), 1633-1639.

Paolisso, M. (1994) Gender differences in care practices of adults in Nepal and Kenya. Report prepared for the Population Council by the International Center for Research on Women, Washington, DC.

Paolisso, M. and Regmi, S. (1995) Agricultural Commercialization, Women's Care Activities, and Child Nutritional Status in Nepal. International Center for Research on Women, Washington, DC.

Pelto, G., Dickin, K. and Engle, P. L. (1999) A Critical Link-Interventions for Physical Growth and Psychological Development. Division of Child and Adolescent Health, World Health Organization, Geneva.

Pitt, M. M. and Rosenzweig, M. R. (1990) Estimating the intrahousehold incidence of illness: Child health and gender-inequality in the allocation of time. International Economic Review 31 (4), 969-988.

Piwoz, E. G., Black, R. E., Lopez de Romaña, G., de Kanashiro, H. C. and Brown, K. H. (1994) The relationship between infants' preceding appetite, illness, and growth performance and mothers' subsequent feeding practice decisions. Social Science and Medicine 39 (6), 851-860.

Piwoz, E. G., de Kanashiro, H. C., Lopez de Romana, G., Black, R. E. and Brown, K. (1995) Potential for misclassification of infants' usual feeding practices using 24-hour dietary assessment methods. Journal of Nutrition 125 (1), 57-65.

Polan, H. J. and Ward, M. J. (1994) Role of the mother's touch in failure to thrive: A preliminary investigation. Journal of the American Academy of Child and Adolescent Psychiatry 33 (8), 1098-1105.

Prentice, A. M., Cole, T. J. and Whitehead, R. G. (1987) Impaired growth in infants born to mothers of very 
high parity. Human Nutrition: Clinical Nutrition 41 (5), 319-325.

Rabiee, F. and Geissler, C. (1992) The impact of maternal work load on child nutrition in rural Iran. Food and Nutrition Bulletin 14 (1), 43-48.

Rahmanifar, A., Kirksey, A., Wachs, T. D., McCabe, G. P., Bishry, Z., Galal, O. M., Harrison, G. G. and Jerome, N. W. (1992) Diet during lactation associated with infant behavior and caregiver interaction in a semi-rural Egyptian village. Journal of Nutrition 123 (21), 164-175.

Ray, W. J. (1997) Methods toward a science of behavior and experience, 5 th ed. Brooks/Cole, Pacific Grove, CA.

Reissland, N. and Burghart, R. (1988) The quality of a mother's milk and the health of her child: Beliefs and practices of the women of Mithila. Social Science and Medicine 27 (5), 461-469.

Ricci, J. A., Jerome, N. W., Aly, H., Moussa, W. A., elGheit, Z. A., Galal, O. M., Harrison, G. G. and Kirksey, A. (1994) Maternal time allocation and children's food consumption in a peri-urban village. Research in Human Capital and Development 8, 277309.

Ricci, J. A., Jerome, N. W., Megally, N., Galal, O., Harrison, G. H. and Kirksey, A. (1995) Assessing the validity of informant recall: Results of a time use pilot study in peri-urban Egypt. Human Organization 54 (3), 304-308.

Richman, A., Miller, P. and LeVine, R. (1992) Cultural and educational variations in maternal responsiveness. Developmental Psychology 28 (4), 614-621.

Richman, A. et al. (1988) Maternal behavior to infants in five cultures. In Parental Behavior in Diverse Societies, ed. R. A. LeVine, P. M. Miller, and M. M. West. Jossey-Bass, San Francisco, CA.

Rogers, B. and Youssef, N. (1988) The importance of women's involvement in economic activities in the improvement of child nutrition and health. Food and Nutrition Bulletin 10 (3), 33-41.

Rutter, M. (1990) Commentary: Some focus and process considerations regarding effects of parental depression on children. Developmental Psychology 26 (1), $60-67$.

Sameroff, A. J. (1989) Commentary: General systems and the regulation of development. In Systems and Development: The Minnesota Symposium on Child Motivation, ed. M. F. Gunnar and E. Thelan. Lawrence Earlbaum Associates, Hillsdale, NJ.

Sanders, M. R., Patel, R. K., Le Grice, B. and Shepherd, R. W. (1993) Children with persistent feeding difficulties: An observational analysis of the feeding interactions of problem and nonproblem eaters. Health Psychology 12 (1), 64-73.

Scrimshaw, S. C. M., Engle, P. L., Arnold, L. and Haynes, K. (1987) Factors affecting breast-feeding among women of Mexican origin or descent in Los Angeles. American Journal of Public Health 77 (4), 467-470.

Shetty, P. S. and James, W. P. T. (1994) Body Mass Index. A Measure of Chronic Energy Deficiency in Adults. FAO Food and Nutrition Paper 56. Food and Agriculture Organization of the United Nations, Rome.
Sigman, M., Neumann, C., Baksh, M., Bwibo, N. and McDonald, M. A. (1989) Relationship between nutrition and development in Kenyan toddlers. Journal of Pediatrics 115, 357-364.

Sims, L. S., Paolucci, B. and Morris, P. M. (1972) A theoretical model for the study of nutritional status: An ecosystem approach. Ecology of Food and Nutrition 1, 197-205.

Tanner, R. E. S. (1959) Sukuma leachcraft: An analysis of their medical and surgical system. East African Medical Journal 36, 119-122.

Thomas, D., Strauss, J. and Henriques, M. H. (1990) How does mother's education affect child height? Journal of Human Resources 26 (2), 183-211.

UN ACC/SCN (United Nations, Administrative Committee on Coordination/Subcommittee on Nutrition) (1992) Second Report on the World Nutrition Situation. Volume 2, Global and Regional Results. United Nations, Geneva.

UNICEF (United Nations Children's Fund) (1989) Iringa: The Child Survival and Development Revolution. Joint Nutrition Support Program. New York.

UNICEF (United Nations Children's Fund) (1990) Strategy for Improved Nutrition of Children and Women in Developing Countries. UNICEF, New York.

UNICEF (United Nations Children's Fund) (1994) The Urban Poor and Household Food Security. Urban Examples No. 19, UNICEF, New York.

United Nations (1995) The World's Women. United Nations, New York.

Valenzuela, M. (1990) Attachment in chronically underweight young children. Child Development 61 (6), 1984-1996.

Van Esterik, P. (1989) Beyond the Breast-Bottle Controversy. Rutgers University Press, New Brunswick, NJ.

Wachs, T. D. and McCabe, G. (1998) The role of the environment in human nutritional research and intervention. In Nutrition, Health, and Child Development: Research Advances and Policy Recommendations. Scientific Publication 566, Pan American Health Organization, Tropical metabolism Research Unit of the University of the West Indies, and The World Bank, Washington, DC.

Wachs, T. D., Sigman, M., Bishry, Z., Moussa, W., Jerome, N., Neumann, C., Bwibo, N. and McDonald, M. A. (1991) Caregiver-child interaction patterns in two cultures in relation to nutrition. International Journal of Behavioral Development 15 (1), 1-18

Wandel, M. and Holmboe-Ottesen, G. (1992a) Maternal work, child feeding, and nutrition in rural Tanzania. Food and Nutrition Bulletin 14 (1), 49-54.

Wandel, M. and Holmboe-Ottesen, G. (1992b) Women's work in agriculture and child nutrition in Tanzania. Journal of Tropical Pediatrics 38 (5), 252-255.

Ware, H. (1984) Effects of maternal education, women's roles, and child care on child mortality. Population and Development Review 10 (Supplement), 191-214.

Weisner, T. S. and Abbott, S. (1977) Women, modernity, and stress: Three contrasting contexts for change in East Africa. Journal of Anthropological Research 33 (4), 1-25. 
Weisner, T. S. and Gallimore, R. (1977) My brother's keeper: Child and sibling caretaking. Current Anthropology 18, 169-190.

Werner, E. E. (1993) Risk, resilience, and recovery: Perspectives from the Kauai Longitudinal Study. Development and Psychopathology 5, 503-515.

WHO (World Health Organization) (1995) Physical Status: The Use and Interpretation of Anthropometry. Report of a WHO Expert Committee. WHO Technical Report Series 851, WHO, Geneva.

Wicker, A. W. (1971) An examination of the 'other variables' explanation of attitude-behavior inconsistency. Journal of Personality and Social Psychology 19.
Winkvist, A. (1995) Health and nutrition status of the caregiver: Effect on caregiving capacity. Food and Nutrition Bulletin 16 (4), 389-397.

Young, M. E. (1995) Investing in Young Children. World Bank Discussion Paper No. 275, World Bank, Washington, DC.

Zeitlin, M., Houser, R. and Johnson, F. C. (1989) Active maternal feeding and nutritional status of 8-20 month old Mexican children. Paper prepared for the Society for Research in Child Development, Kansas City, MO. 